\title{
Study on Real-Time Porosity Defect Detection Through Neural Network Structure Optimization using Genetic Algorithm in GMAW
}

\author{
GMAW에서 유전알고리즘을 이용한 신경망 구조 최적화를 통해 \\ 실시간 기공 형상검출에 관한 연구 \\ Dongwook Lee*, Chengnan Jin**, and Sehun Rhee**, $\dagger$ \\ *Department of Mechanical Engineering, Hanyang University, Seoul, 04763, Korea \\ **Department of Mechanical Convergence Engineering, Hanyang University, Seoul, 04763, Korea
}

†Corresponding author: srhee@hanyang.ac.kr

(Received March 16, 2021; Revised August 10, 2021; Accepted August 16, 2021)

\begin{abstract}
Zinc-coated steel sheets are widely applied as automotive chassis parts because they have high corrosion resistance and good compatibility. However, in the gas metal arc welding (GMAW) process, serious porosity defects occur due to zinc vapor generated during welding, which causes problems such as durability or productivity reduction in the welded structure. To secure weldability and productivity, it is essential to secure monitoring technology that determines whether porosity defects are generated in real-time. To solve this problem, this study provides a method of extracting feature variables from arc voltage signals generated during welding and optimizing the hyper parameters of the porosity detection algorithm deep neural network (DNN) which be learned with feature variables by applying genetic algorithm (GA). To verify the performance of the proposed method, as a result of applying it to the optimized DNN model using the experimental data of the GMAW experiment using a high-strength zinc-coated steel sheet, a prediction accuracy of $93.1 \%$ was derived, which is improved by $3.60 \%$ than DNN model from previous research.
\end{abstract}

Key Words: Gas metal arc welding, Genetic algorithm, Deep neural network, Hyper parameter optimization

\section{Introduction}

Gas metal arc welding (GMAW) is a method of welding by creating an arc between a wire and the base metal which is protected by a shielding gas consisting of inert gas. It is possible to automatically feed the wire to perform robot welding or automated welding, and GMAW is mainly used together with galvanized steel sheets to manufacture automobile chassis. However, when GMAW is used on galvanized steel sheets, the zinc plating on the surface is vaporized at a temperature that is lower than the base metal's melting point. As a result, the zinc vapor becomes trapped in the weld and cannot escape, and porosity defects such as blow holes and pits occur ${ }^{1-3)}$. These defects are a major factor in reducing weld quality and productivity ${ }^{4}$. To detect these defects, studies have been conducted on detecting porosity defects by analyzing the properties of arc voltage signals that occur during arc welding as an alternative to non-destructive inspections such as radiographic inspections and ultrasound inspections that can only be performed after the welding process is finished ${ }^{5-11)}$. Such methods are more cost-effective than existing non-destructive inspection methods, and they can improve productivity in terms of time spent.

Deep learning techniques are used in a variety of fields in addition to quality prediction algorithms ${ }^{12-14)}$. However, most of the studies that have employed such neural networks have not described how the neural network model's hyper parameters are selected, and there are many cases where these values are simply presented. Because the researchers go through a process of finding the best structure by personally performing tests, there 
is clearly a need for improvement in this area.

Complex problems can be solved by increasing the number of hidden layers in a deep learning structure. However, when training is performed on a neural network that has many hidden layers to solve relatively simple problems, such as when the training data set is small or the training data have a simple format, feature values with low importance are extracted, which causes overfitting and lowers the model's generalization performance ${ }^{14)}$. Because the problems that can be solved by a neural network vary according to the neural network's structure in this way, the task of properly selecting hyper parameters is very important. Because the hyper parameters of artificial neural networks are so various, it is counterproductive to find the optimal structure by testing hyper parameters for all cases. Therefore, many studies have been conducted on using genetic algorithms to optimize these variables ${ }^{16,17)}$. Genetic algorithms find optimal solutions based on randomness, and the more samples there are, the easier it is to find the global optimal solution ${ }^{16)}$. However, this has a drawback in that the amount of computation increases as the number of samples increases, and the computation time becomes longer.

Therefore, this study proposes a new algorithm that reduces computation time by adjusting the population of chromosomes in each generation. In order to use the genetic algorithm, galvanized steel sheet GMAW experiments were conducted to extract feature variables according to whether or not porosity occurred in the arc voltage signals that were generated during the welding process. Then, the deep neural network (DNN) model was trained, and the DNN model's hyper parameters were optimized using the genetic algorithm proposed by this study. Lastly, the validity of the proposed optimization algorithm was verified by comparing its performance to a previous study's DNN structure ${ }^{11)}$.

\section{Experiments}

\subsection{Materials}

In this study, a hot-rolled galvanized steel sheet with an ultimate strength of $590 \mathrm{Mpa}$ and a thickness of 2.3 $\mathrm{mm}$ was used as the test material. The hot-rolled steel sheet that was used was manufactured by passing a slab between rolls at a temperature of $800^{\circ} \mathrm{C}$ to shape it into the proper length and width. The material's zinc plating thickness was around $10 \mu \mathrm{m}$, and its mechanical and chemical properties are shown in Table 1 . The sheet was manufactured to have a width of $150 \mathrm{~mm}$ and a length of $180 \mathrm{~mm}$.
Table 1 Mechanical and chemical properties of the material

\begin{tabular}{|c|c|c|c|c|c|c|c|c|c|}
\hline $\begin{array}{c}\text { Base } \\
\text { metal }\end{array}$ & \multicolumn{4}{|c|}{$\begin{array}{c}\text { Chemical } \\
\text { composition }\end{array}$} & \multicolumn{3}{c|}{$\begin{array}{c}\text { Mechanical } \\
\text { properties }\end{array}$} \\
\hline \multirow{2}{*}{$\begin{array}{c}\text { GA } \\
590\end{array}$} & $\mathrm{C}$ & $\mathrm{Si}$ & $\mathrm{Mn}$ & $\mathrm{P}$ & $\mathrm{S}$ & $\mathrm{Fe}$ & $\begin{array}{c}\text { YS } \\
(\mathrm{MPa})\end{array}$ & $\begin{array}{c}\mathrm{TS} \\
(\mathrm{MPa})\end{array}$ & $\begin{array}{c}\text { EL } \\
(\%)\end{array}$ \\
\cline { 2 - 10 } & 0.0817 & 0.136 & 1.440 & 0.013 & 0.002 & Bal. & 583 & 629 & 25 \\
\hline
\end{tabular}

\subsection{Welding Equipment and Process}

The welding experiments were conducted in short circuit transfer mode using a constant voltage direct current inverter-type electric welder. The overall configuration of the welding system is shown in Fig. 2. The welding workpiece was fixed above the jig by a lap joint, and the welding current between the welder and the jig was measured by a hall sensor and transmitted to a DAQ device. The welding voltage was measured in real-time from the workpiece and the wire feeder by the DAQ device. As the welding style, this study used the lap joint style with a torch angle of $45^{\circ}$, which is often used in automobile body chassis welding sites.

As shown in Table 2, the welding speed was 600 $\mathrm{mm} / \mathrm{min}$, and the distance between the contact tip and

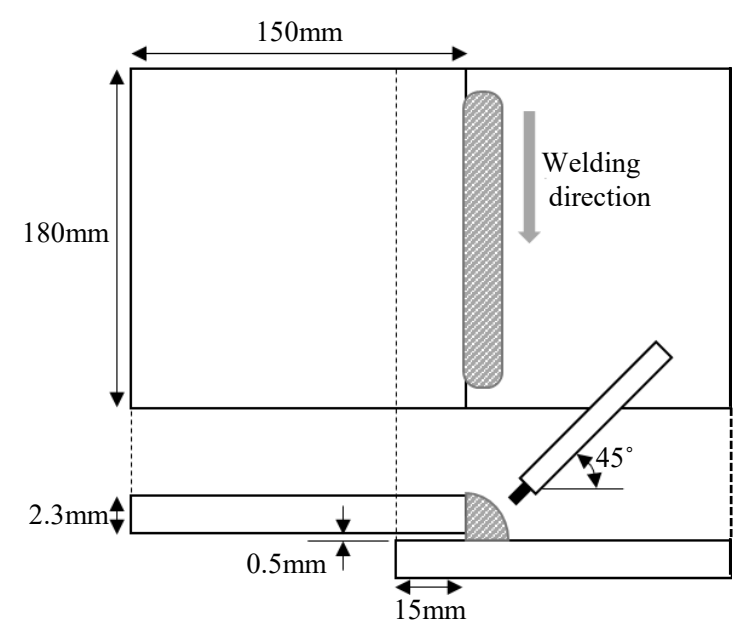

Fig. 1 Welding method and shape of steel plate

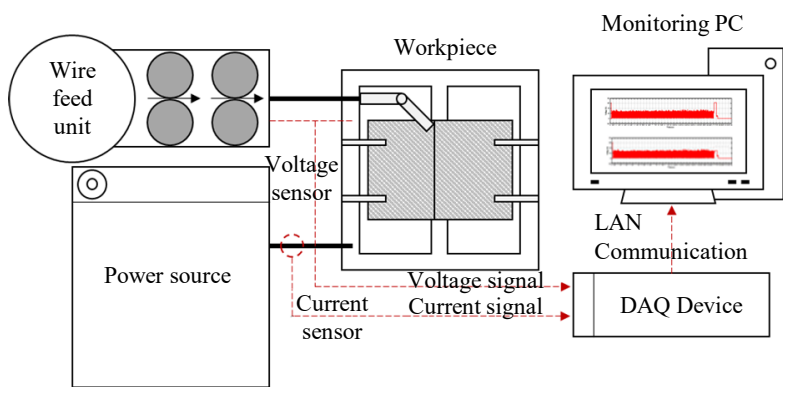

Fig. 2 Schematic diagram of welding and experimental equipment 
Table 2 Welding test conditions

\begin{tabular}{|c|c|}
\hline Gap $(\mathrm{mm})$ & $0,0.5$ \\
\hline CTWD $(\mathrm{mm})$ & 15 \\
\hline WFR $(\mathrm{m} / \mathrm{min})$ & 4 \\
\hline $\begin{array}{c}\text { Welding speed } \\
(\mathrm{mm} / \mathrm{min})\end{array}$ & 600 \\
\hline Shielding gas & $\operatorname{Ar}(90 \%): \mathrm{CO}_{2}(10 \%)$ \\
\hline
\end{tabular}

the base metal (CTWD) was fixed at $15 \mathrm{~mm}$. The shielding gas was mixed at a ratio of $90 \% \mathrm{Ar}$ and $10 \%$ $\mathrm{CO}_{2}$, and the gaps between the workpieces were fixed at $0.0 \mathrm{~mm}$ and $0.5 \mathrm{~mm}$. Also, an ER70S-3 level wire with a diameter of $1.2 \mathrm{~mm}$ was used, and the experiments were conducted at a wire feed rate of $4 \mathrm{~m} / \mathrm{min}$. For reliability, the experiments were repeated two times under each set of conditions.

\section{Genetic Algorithm}

\subsection{Genetic Algorithm Optimization Technique}

Genetic algorithms do not test each of the variables for all cases, but find optimal solutions using randomnesses, such as parent selection, crossover operations, and mutation operations. The major advantage of genetic algorithms is that an appropriate solution can be found by the algorithm if the algorithm designer can represent the format of the solution as a genetic configuration and set up an appropriate fitness function, even in regards to problems for which no concrete method of solving them has been presented.

Fig. 3 shows a flowchart for the genetic algorithm. The first generation's set of chromosomes is shown in Eq. (1).

$$
P_{1}=\left\{p_{1,1}, p_{1,2}, p_{1,3}, \cdots, p_{1, n}\right\}
$$

In the equation above, $P_{i}$ is the set of chromosomes

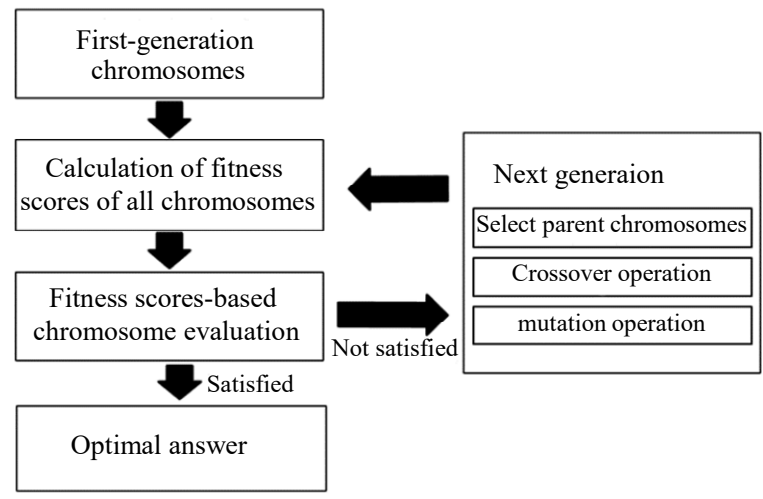

Fig. 3 Genetic algorithm flowchart for the ith generation. $n$ is the total number of chromosomes (population). $p_{i, j}$ is the $\mathrm{jth}$ chromosome of the ith generation. The genetic information of the first chromosome of the first generation $\left(p_{1,1}\right)$ is shown in Eq. (2).

$$
p_{1,1}=\left\{q_{1,1,1}, q_{1,1,2}, q_{1,1,3}, \cdots, q_{1,1, m}\right\}
$$

$q$ is the values of the genetic information of each chromosome. $\mathrm{m}$ is the number of types of genetic information of each chromosome. $q_{i, j, k}$ is the kth genetic information value of $p_{i, j}$, which is the jth chromosome in the ith generation. Generally, the genetic information value $\mathrm{q}$ is given minimum and maximum value limits and assigned a random value in the initial generation.

An appropriate function evaluates all of the $n$ number of chromosomes in the first generation chromosome set $P_{1}$, which has chromosomes that were given genetic information values.

$$
p_{i, j, s c o r e}=f\left(p_{1, j}\right)
$$

$f$ is the fitness function, and the genetic algorithm designer must configure it personally. If one or more of the chromosomes that have been evaluated by the appropriate function $f$ has a score that is greater than or equal to the expected appropriate value, it becomes the optimal solution, and if not, the next generation is generated using the first generation chromosomes which were given scores. Roulette wheel selection was used, which is a method that probabilistically selects two chromosomes with a probability that increases as their fitness scores increase. When the first generation's $\mathrm{a}^{\text {th }}$ $\left(p_{1, a}\right)$ and $\mathbf{b}^{\text {th }}\left(p_{1, b}\right)$ chromosomes are selected as shown in Eqs. (4) and (5) below, the crossover operation is performed.

$$
\begin{aligned}
& p_{1, a}=\left\{q_{1, a, 1}, q_{1, a, 2}, q_{1, a, 3}, \cdots, q_{1, a, m}\right\} \\
& p_{1, b}=\left\{q_{1, b, 1}, q_{1, b, 2}, q_{1, b, 3}, \cdots, q_{1, b, m}\right\}
\end{aligned}
$$

The arithmetic crossover was chosen from among a number of methods ${ }^{18)}$ that have already been proposed as crossover methods for chromosomes that have gene values in real number format. The first descendent chromosome in the second generation that was created after crossover is called $p_{2,1}$, and it is shown in Eq. (6).

$$
p_{2,1}=\left\{\left\{q_{2,1,1}, q_{2,1,2}, q_{2,1,3}, \cdots, q_{2,1, m}\right\}\right\}
$$

Eq. (7) shows $p_{2,1}$, which is the kth gene value of $q_{2,1, k}$ that was produced by arithmetic crossover.

$$
q_{2,1, k}=\alpha_{k} \cdot q_{1, a, k}+\left(1-\alpha_{k}\right) \cdot q_{1, b, k}
$$




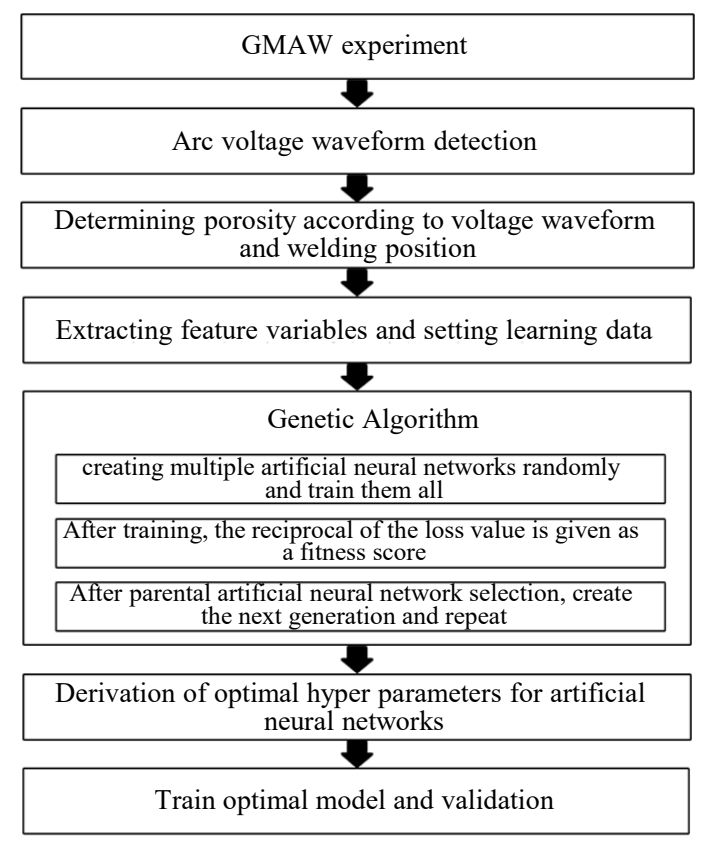

Fig. 4 Genetic algorithm optimization flow chart

$\alpha_{k}$ has a random value between 0 and 1 . That is, $q_{2,1, k}$, which is the kth gene value of the descendent $p_{2,1}$, has a random value between the kth gene value of the $a^{\text {th }}$ chromosome in the first generation and the kth gene value in the $b^{\text {th }}$ chromosome in the first generation. After the crossover operation is performed in this way, a mutation operation is performed to generate the second generation of chromosomes by changing gene values randomly with certain probabilities. Then, the fitness function $f$ is used to perform evaluation again and determine whether a subsequent generation will be generated.

In this study, such a genetic algorithm was used as shown in Fig. 4 to optimize the hyper parameters of the artificial neural network for predicting GMAW defects. After the GMAW experiments, the arc voltage waveform feature variables were extracted, and the porosity according to the weld location was used as training data. The genetic algorithm was used to find the optimal hyper parameters for the neural network, and the optimized neural network was trained and verified.

The ReLU function was used as the activation function for the hidden layers of the neural network that will perform optimization. The output was 1 if there was a defect and 0 if there was no defect, and the softmax function, which is effective at processing the classification of multiple classes, was used as the activation function of the output layer.

\subsection{Selecting Deep Learning Hyperparameters}

The deep neural network shown in Fig. 5 has a struc-

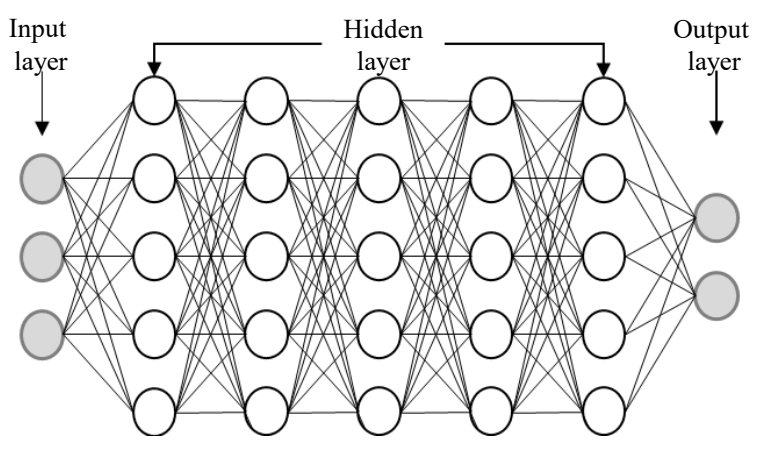

Fig 5 Deep neural network structure

Table 3 Hyper parameters from previous research ${ }^{11)}$

\begin{tabular}{|c|c|}
\hline \multicolumn{2}{|c|}{ Hyper parameters from previous research ${ }^{11)}$} \\
\hline Number of hidden layer & 4 \\
\hline Number of node in each layer & $24,24,24,24$ \\
\hline Learning rate & 0.01 \\
\hline Batch size & 32 \\
\hline Dropout rate & 0.5 \\
\hline
\end{tabular}

ture in which perceptrons have been arranged in several layers. Learning is performed using a method that finds the optimal weight values for each node by adjusting the weights using an error back-propagation algorithm. The hyper parameters that were optimized in this study were primarily the number of hidden layers and the number of nodes that each hidden layer has. When these numbers are too large, the overfitting phenomenon occurs, and the neural network's generality declines ${ }^{15)}$. In addition, there are several parameters in the artificial neural network learning process, including the learning rate, batch size, and dropout rate ${ }^{19)}$, and these were also optimized. Table 3 shows a comparison of the optimization results and a previous study's ${ }^{11)}$ DNN structure.

\subsection{Genetic Algorithm-based Optimization}

The hyper parameters that were selected in Section 3.2 were assigned to chromosomes as gene values in real number format, and the genetic information in the chromosomes was the number of hidden layers, number of nodes in each layer, learning rate, batch size, and dropout rate. The ranges for each of the gene values were set as 1-10 for the number of hidden layers, 10-50 for the number of nodes in each hidden layer, $0-0.2$ for the learning rate, 100-10000 for the batch size, and 0-0.8 for the dropout rate.

The chromosomes of the first generation were randomly configured with gene values within the ranges above. In this study, the population of the first gen- 
eration was set at 256 . The artificial neural networks that correspond to each of the 256 randomly generated chromosomes were all trained to find out whether they had structures that were appropriate for the training data. After training was completed, the reciprocal value of the loss (MSE) that occurred for the test data, which consisted of data other than the training data, was used as the fitness score. Higher scores indicated better chromosomes.

After the fitness scores of all chromosomes in the first generation were calculated in this way, the parent chromosomes were selected using the roulette wheel selection style, which assigns probabilities to chromosomes by using the fitness scores as weight values. Next, the second generation of chromosomes was generated using the arithmetic crossover and mutation operations. In existing generation algorithms, the process above can be continuously repeated, but in this study, several rules were also applied to the number of chromosomes (population) in each generation.

Other previous papers that have used genetic algorithms ${ }^{20,21)}$ usually had populations in which all generations were the same. Fig. 6(a) is an example of an existing genetic algorithm being used in this optimization study. Fig. 6(b) is the new, improved algorithm being presented in this paper. The number of chromosomes decreased as the algorithm went through the generations, and the epoch was increased slightly compared to the previous generation as the algorithm progressed. An analysis was performed, focusing on the descendent chromosomes that were selected in the previous generation. The steps between the first and second generations are shown in Fig. 6, and the same method was used from thereon. Also, a minimum num-

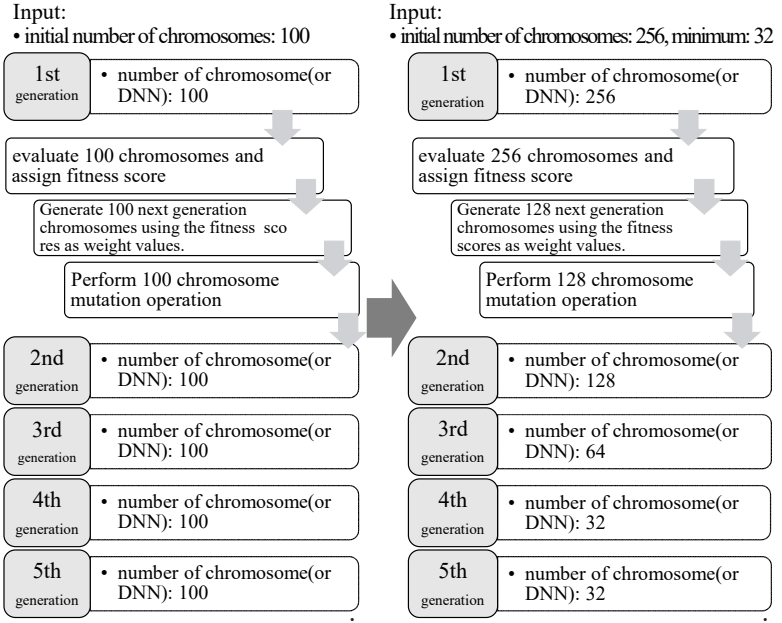

(a)

(b)
Fig. 6 Improved genetic algorithm, (a) Usual genetic algorithm, (b) Improved genetic algorithm in this study ber of chromosomes was set to prevent the number of chromosomes in a single generation from becoming too small. The result of these improvements was that the time spent producing similar optimal hyper parameters was reduced by around 30\% compared to before. Using the shortened time, the number of chromosomes (population) in the first generation was set to be around twice as large as the existing algorithm, and the diversity of the initial chromosomes was also improved.

\section{Results and Observations}

\subsection{Signal Analysis and Feature Extraction}

Fig. 7 shows the bead shapes, x-ray images, and welding voltage waveforms that were captured during 20 seconds of welding experiments at a sampling rate of $10 \mathrm{kHz}$. For the waveform voltage data, sampling data were taken at 0.1 -second intervals (1000 data items) from the raw measurement data, and this was assigned to a single window. A $90 \%$ overlap was performed, and feature variables were found for each window. Fig. 8 shows the short circuit transfer mode arc voltage waveforms that were generated during a 0.1 -second interval window, and each of the variables was found based on the 1000 data items during the 0.1 -second interval. $V_{p}$ and $V_{s}$ are the maximum and minimum voltage data values during the 0.1 -second, respectively. $s[V]$ is the standard deviation for the 0.1 -second of data. $s\left[V_{s}\right]$ is the standard deviation of the voltage data during 5 instantaneous short circuits (orange circles). $s\left[V_{p}\right]$ is the standard deviation of the voltage data during 5 peaks (blue circles). $s\left[T_{a}\right]$ is the standard deviation of the arc periods within 0.1 -second. $s\left[V\left(T_{s}\right)\right]$ and $s\left[V\left(T_{a}\right)\right]$ are the standard deviation values of voltages measured during the short circuit periods and the arc periods, respectively. Table 4 shows each of these variables.

\subsection{Results of Optimization Using a Genetic Algorithm}

Optimization was performed using the variables in Table 5 below based on the algorithm presented in Section 3.2. Table 6 shows all of the chromosomes that were generated during the optimization process. The neural networks were arranged in descending order starting with the neural network that had the highest fitness score. The total number of generated chromosomes was 1216 (256 in the first generation, 128 in the second generation, 64 in generations ${ }^{3-15)}$, and the top 12 are shown in Table 6.

The maximum value for the number of hidden layers was set at 10 layers, but it was found that the numbers 

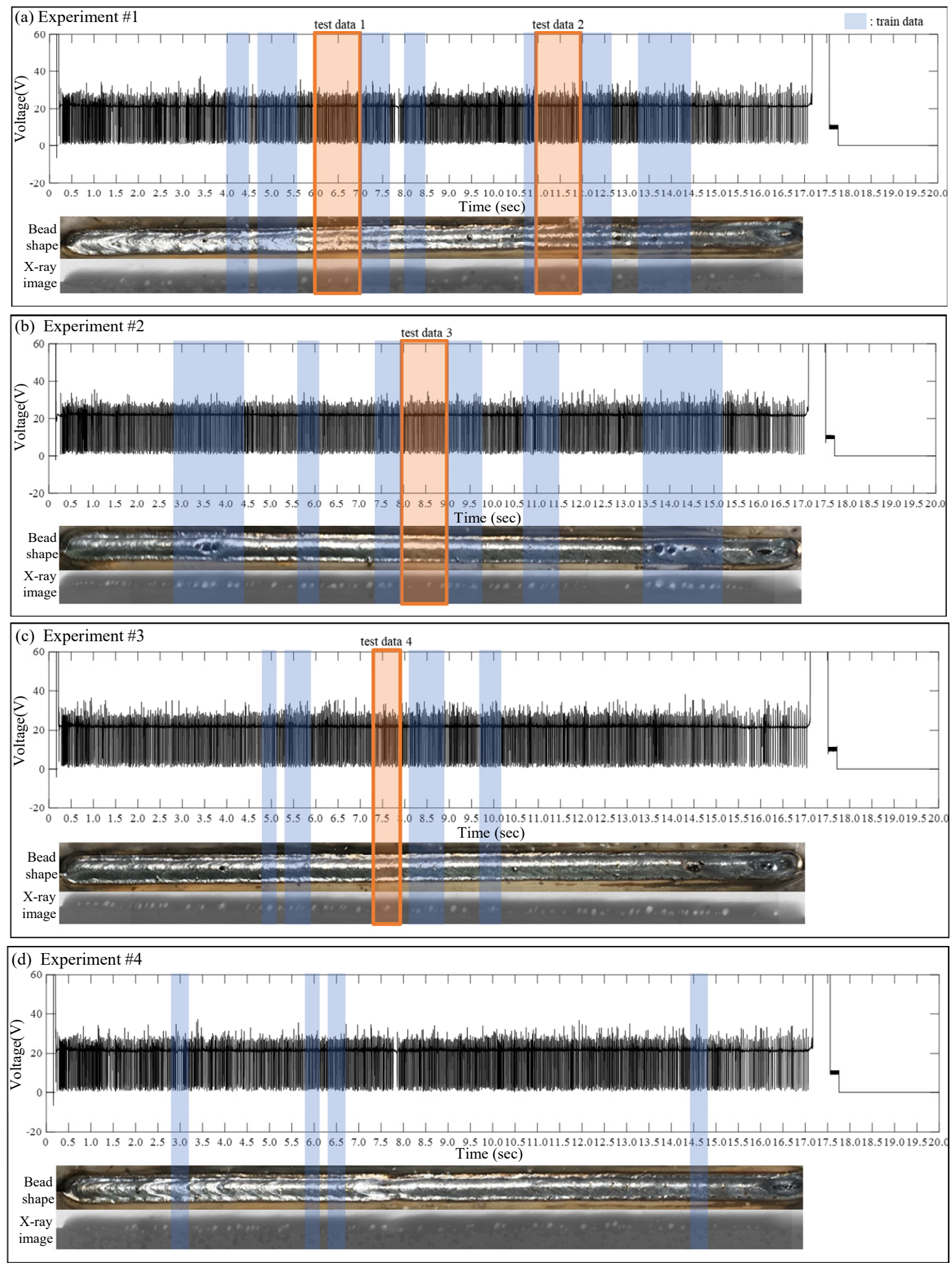

Fig. 7 Voltage waveform, bead shape, x-ray image and train, test data, (a) result of experiment \#1, (b) result of experiment $\# 2$, (c) result of experiment \#3, (d) result of experiment \#4

of hidden layers in the top-level chromosomes converged at 3 layers. From this result, it was found that the artificial neural network did not always improve as its number of hidden layers increased. In addition, the results were consistent with previous studies on overfitting ${ }^{15}$. The batch size was 5000; the learning rate was around 0.02 , and the dropout rate tended to be around 0.1 . The optimal value was judged to be significant because optimization was performed with a maximum learning rate of 0.2 and a maximum dropout rate of 0.8 . Table 7 below shows a comparison of (b) the chromosome with the highest fitness score in Table 


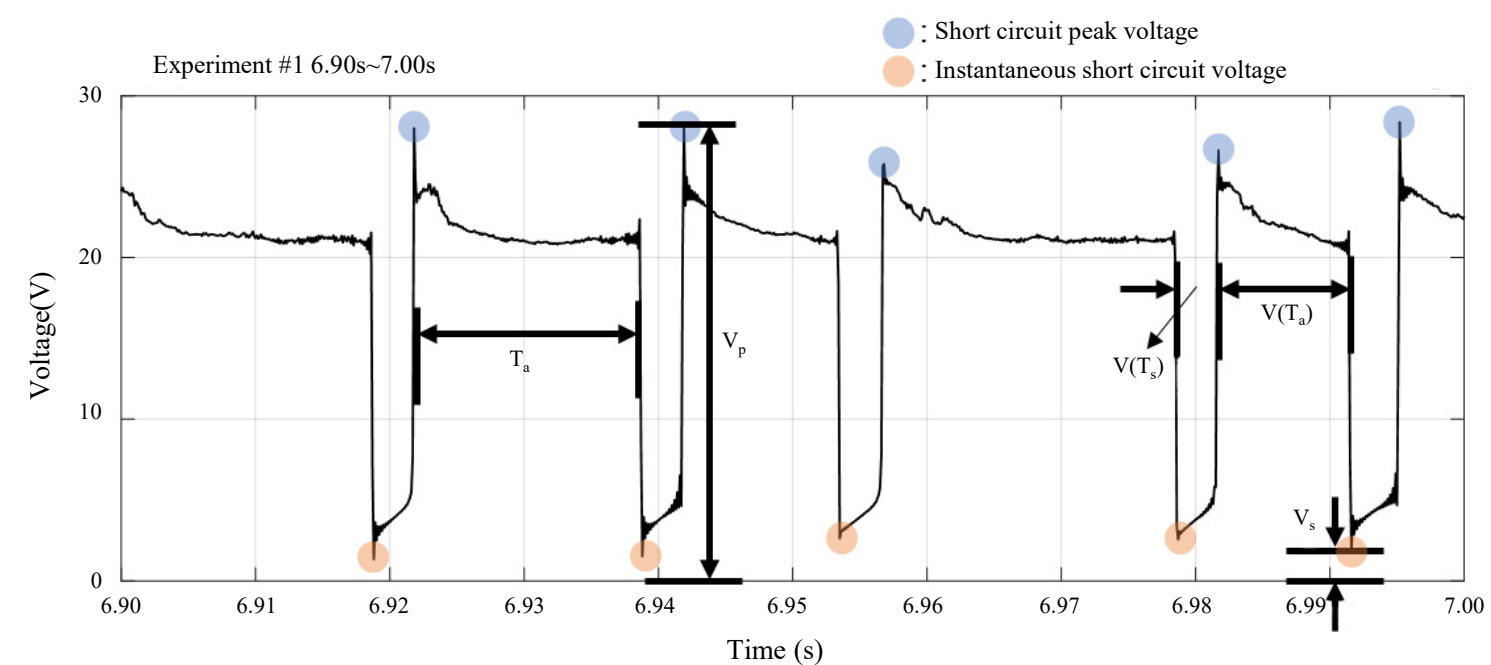

Fig. 8 Arc voltage waveform and feature variables

Table 4 Feature variables

\begin{tabular}{|c|l|}
\hline Variables & \multicolumn{1}{|c|}{ Name } \\
\hline$s[V]$ & Standard deviation of voltage \\
\hline$V_{p}$ & peak voltage \\
\hline$V_{s}$ & short circuit voltage \\
\hline$s\left[V_{s}\right]$ & $\begin{array}{l}\text { Standard deviation of } \\
\text { instantaneous short circuit voltage }\end{array}$ \\
\hline$s\left[V_{p}\right]$ & $\begin{array}{l}\text { Standard deviation of } \\
\text { short circuit peak voltage }\end{array}$ \\
\hline$s\left[T_{a}\right]$ & Standard deviation of arc time \\
\hline$s\left[V\left(T_{s}\right)\right]$ & $\begin{array}{l}\text { standard deviation of } \\
\text { voltage during short circuit time }\end{array}$ \\
\hline$s\left[V\left(T_{a}\right)\right]$ & $\begin{array}{l}\text { standard deviation of } \\
\text { voltage during arc time }\end{array}$ \\
\hline
\end{tabular}

Table 5 Genetic algorithm variables

\begin{tabular}{|l|c|}
\hline \multicolumn{1}{|c|}{ Variables } & Value \\
\hline Initial number of chromosomes & 256 \\
\hline Minimum number of chromosomes & 64 \\
\hline Maximum generation & 15 \\
\hline mutation probability & $15 \%$ \\
\hline
\end{tabular}

6 and (a) the previous study's DNN artificial neural network structure shown in Table 3. The training was performed on the previous study's DNN model (a) and the optimized model (b) from Table 7 for 1500 epochs each with the GMAW welding data, and Fig. 9 shows the defect prediction results, bead shapes, and x-ray im-

Table 6 Neural network optimization results for GMAW experiment data

\begin{tabular}{|c|c|c|c|c|c|c|c|c|c|c|c|c|c|c|c|}
\hline \multirow{2}{*}{$\begin{array}{c}\text { Hidden } \\
\text { layer } \\
\text { number }\end{array}$} & \multicolumn{10}{|c|}{ Number of nodes in each hidden layer } & \multirow{2}{*}{$\begin{array}{c}\text { batch } \\
\text { size }\end{array}$} & \multirow{2}{*}{$\begin{array}{l}\text { learning } \\
\text { rate }\end{array}$} & \multirow{2}{*}{$\begin{array}{l}\text { dropout } \\
\text { rate }\end{array}$} & \multirow{2}{*}{$\begin{array}{c}\text { Fitness } \\
\text { scores }\end{array}$} & \multirow{2}{*}{$\begin{array}{c}\text { Generation } \\
\text { that } \\
\text { emerged }\end{array}$} \\
\hline & $1 \mathrm{st}$ & 2nd & $3 r d$ & 4 th & 5 th & 6th & 7 th & 8 th & 9th & 10 th & & & & & \\
\hline 3 & 37 & 31 & 40 & 32 & 16 & 24 & 20 & 14 & 19 & 18 & 5671 & 0.009521 & 0.105286 & 7.538489 & 14 \\
\hline 3 & 21 & 21 & 33 & 48 & 11 & 29 & 22 & 45 & 34 & 42 & 4500 & 0.025116 & 0.086827 & 7.513469 & 15 \\
\hline 3 & 34 & 36 & 31 & 32 & 36 & 45 & 27 & 36 & 34 & 24 & 4652 & 0.017252 & 0.072461 & 7.439683 & 6 \\
\hline 3 & 39 & 20 & 49 & 34 & 35 & 31 & 44 & 32 & 24 & 24 & 6098 & 0.02577 & 0.077352 & 7.435625 & 13 \\
\hline 2 & 49 & 30 & 25 & 39 & 30 & 25 & 43 & 28 & 32 & 25 & 4836 & 0.019425 & 0.163282 & 7.429222 & 4 \\
\hline 3 & 39 & 25 & 34 & 47 & 33 & 31 & 34 & 31 & 33 & 35 & 6394 & 0.03833 & 0.135442 & 7.423678 & 5 \\
\hline 5 & 30 & 22 & 33 & 46 & 29 & 33 & 23 & 47 & 36 & 29 & 3028 & 0.02122 & 0.099924 & 7.419714 & 13 \\
\hline 2 & 35 & 37 & 31 & 37 & 34 & 45 & 24 & 30 & 23 & 20 & 4515 & 0.051841 & 0.069824 & 7.404039 & 7 \\
\hline 1 & 32 & 39 & 41 & 36 & 30 & 26 & 38 & 24 & 35 & 34 & 5311 & 0.036818 & 0.1495 & 7.380273 & 14 \\
\hline 2 & 29 & 37 & 29 & 23 & 23 & 25 & 30 & 32 & 33 & 35 & 6800 & 0.038247 & 0.149579 & 7.376929 & 4 \\
\hline 3 & 37 & 27 & 13 & 31 & 42 & 31 & 31 & 27 & 33 & 34 & 2158 & 0.033415 & 0.085455 & 7.372247 & 11 \\
\hline 3 & 41 & 28 & 28 & 27 & 25 & 31 & 32 & 29 & 30 & 40 & 2614 & 0.031224 & 0.082894 & 7.366977 & 10 \\
\hline
\end{tabular}


Table 7 Comparison of hyper parameters, (a) DNN structure from previous research, (b) Optimized GADNN structure

\begin{tabular}{|l|c|c|}
\hline & $\begin{array}{l}\text { DNN structure from } \\
\text { previous research (a) }\end{array}$ & $\begin{array}{c}\text { Optimized GA- } \\
\text { DNN structure (b) }\end{array}$ \\
\hline $\begin{array}{l}\text { Number of } \\
\text { hidden layer }\end{array}$ & 4 & 3 \\
\hline $\begin{array}{l}\text { Number of node } \\
\text { in each layer }\end{array}$ & $24,24,24,24$ & $37,31,40$ \\
\hline learning rate & 0.01 & 0.009521 \\
\hline batch size & 32 & 5671 \\
\hline dropout rate & 0.5 & 0.105286 \\
\hline
\end{tabular}

Table 8 Predictive accuracy for each model

\begin{tabular}{|l|c|c|c|c|}
\hline & $\begin{array}{c}\text { Total } \\
\text { test data }\end{array}$ & True & Error & accuracy \\
\cline { 1 - 4 } $\begin{array}{l}\text { DNN structure } \\
\text { from previous } \\
\text { research }\end{array}$ & 361 & 323 & 38 & 89.4737 \\
\cline { 1 - 1 } $\begin{array}{l}\text { Optimized GA- } \\
\text { DNN structure }\end{array}$ & & 336 & 25 & 93.0748 \\
\hline
\end{tabular}

ages, while Table 8 shows the detailed figures for these results.

The total number of test data that were used for verification was 361. The previous study's DNN model accurately classified 323 data and had 38 errors for an accuracy of $89.5 \%$. The DNN model that was optimized with the genetic algorithm accurately classified 336 data and had 25 errors for an accuracy of $93.1 \%$. The optimized model's prediction accuracy was better by $3.60 \%$. The number of errors was reduced from 38 to 25 for a reduction rate of $34.2 \%$.

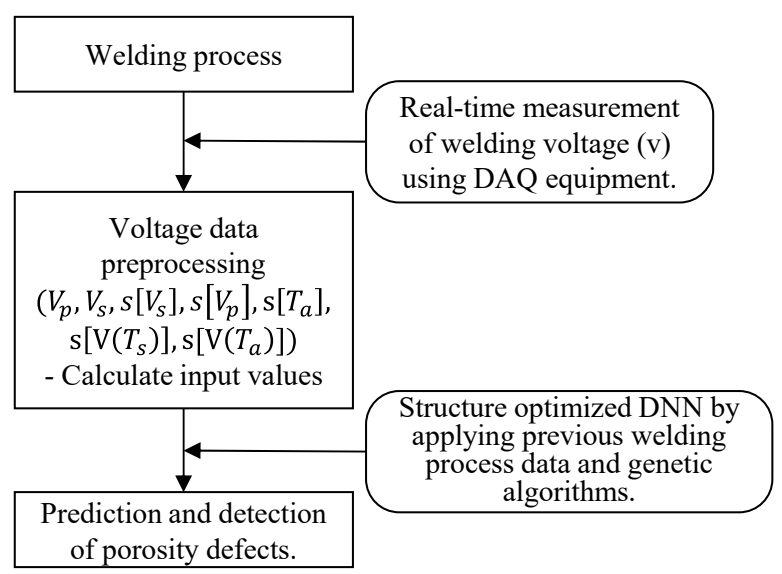

Fig. 10 Process of GMAW porosity defects prediction with GA-DNN structure in real-time

\subsection{System for Real-time Use After Optimization}

This study proposes a system for real-time prediction of porosity defects that occur during GMAW using an optimized GA-DNN structure, as shown in Fig. 10. As in a previous study ${ }^{11}$, the welding voltage is measured in real-time by a DAQ device, and feature variables are extracted through a data preprocessing step and used as input values. A considerable amount of time is spent performing optimization with the genetic algorithm, but when the input values are entered in the DNN structure that has been pre-optimized with the previous welding process' data and the genetic algorithm, the porosity defect location prediction values are calculated right away. It is thought that the DNN structure can be periodically optimized and improved using the welding data that are obtained as the welding process is repeatedly performed on-site.
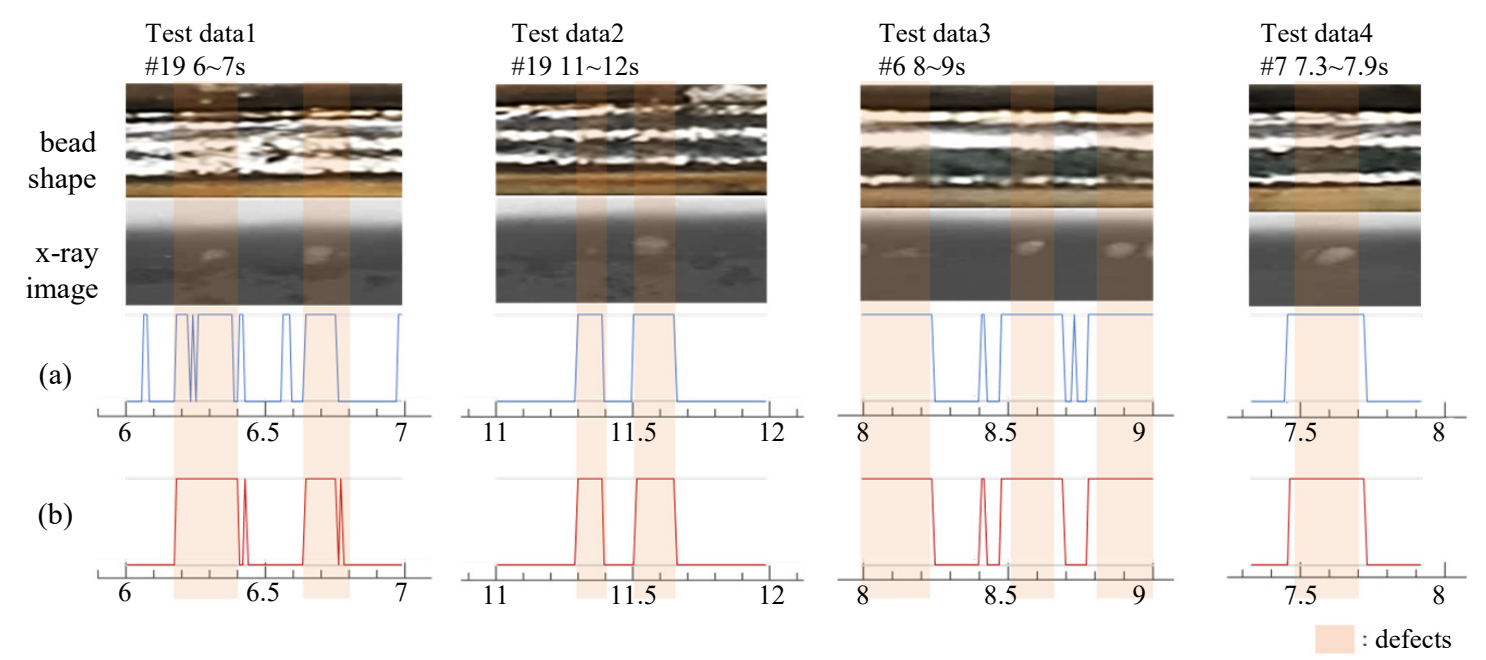

Fig. 9 Porosity defects prediction from DNN, (a) Prediction from previous research DNN structure, (b) Prediction from optimized GA-DNN structure 


\section{Conclusions}

This study extracted feature variables from GMAW experiment results and used a genetic algorithm to optimize the hyper parameters of a deep neural network that detects the presence of porosity, and it was confirmed that the results of this approach improved performance. This approach makes it possible to automatically design neural networks that are suitable for each different welding environment, even though the welding equipment that is used or the automobile type, etc. may vary. By using this porosity defect detection algorithm, it will be possible to further maximize improvements in regards to time and cost. Moreover, it is thought that this genetic algorithm approach can be applied not only to welding data but also to other types of training.

Below is a summary of the areas and conclusions that have been developed in this study.

1) Feature variables were derived by measuring the arc voltage waveforms that occur during the GMAW process in real-time and performing data preprocessing.

2) The new genetic algorithm that was proposed by this study reduced calculation time by around 30\% compared to before and increased the number of firstgeneration chromosomes, thus improving the diversity of the initial chromosomes.

3) The results of verifying the optimization results showed that the DNN model that was optimized by the genetic algorithm had a prediction accuracy of $93.1 \%$, which was an increase of $3.60 \%$ compared to a previous study's DNN model prediction rate.

However, in order to increase the algorithm's generality and use the algorithm in a variety of areas, it will be necessary to make improvements such as automatically selecting specific items like the layer activation functions that are used. These issues will be improved upon in follow-up studies.

\section{Acknowledgment}

This work was supported by "Human Resources Program in Energy Technology" of the Korea Institute of Energy Technology Evaluation and Planning (KETEP), granted financial resource from the Ministry of Trade, Industry \& Energy, Republic of Korea. (No. 20204030200100)

ORCID: Dongwook Lee: https://orcid.org/0000-0003-0426-2238 ORCID: Chengnan Jin: https://orcid.org/0000-0001-7964-5466 ORCID: Sehun Rhee: https://orcid.org/0000-0002-0039-5650

\section{References}

1. S. Kodama, Y. Ishida, S. Furusako, M. Saito, Y. Miyazaki, and T. Nose, Arc Welding Technology for Automotive Steel Sheets, Nippon Steel Technical Report. 103 (2013) 83-90.

2. Y. Mukai, A. Nishimura, A. Nakajima, and K. Oku, $\mathrm{CO}_{2}$ welding of galvanized steel, Weld. Int. 4(2) (1990) 123-127.

3. M. Uchihara, Joining technologies for automotive steel sheets, Weld. Int. 25(04) (2011) 249-259.

4. K. Yasuda, Avoidance of blowhole in arc welding of galvanized steel sheets, In 5th International Symposium of JWS. (1990).

5. M. J. Kang and S. Rhee, The statistical models for estimating the amount of spatter in the short circuit transfer mode of GMAW, Weld. J. 80(1) (2001) 1-8.

6. S. K. Kang, H. S. Moon, and S. J. Na, A study on determining arc stability using weight of spatter, J. Korean Weld. Join. Soc. 15(6) (1997) 527-534.

7. C. S. Wu, J. Q. Gao, and J. K. Hu, Real-time sensing and monitoring in robotic gas metal arc welding, Meas. Sci. Technol. 18(1) (2006) 303-310.

8. Z. Zhang, X. Chen, H. Chen, J. Zhong and S. Chen, Online welding quality monitoring based on feature extraction of arc voltage signal, Int. J. Adv. Manuf. Technol. 70 (9-12) (2014) 1661-1671.

9. S. J. Na and H. S. Moon, Signal processing algorithm for analysis of welding phenomena, J. Korean Weld. Join. Soc. 14(4) (1996) 24-32.

10. J. S. Sin, J. W. Kim, and S. J. Na, A Study on Monitoring of Welding Waveforms in Gas Metal Arc Welding, $J$. Korean Weld. Join. 9(03) (1991) 34-40.

11. S. Shin, C. Jin, J. Yu, and S. Rhee, Real-time detection of weld defects for automated welding process base on deep neural network, Metals. 10(3) (2020) 389. https://doi.org/10.3390/met10030389

12. L. Perez and J. Wang, The effectiveness of data augmentation in image classification using deep learning, arXiv preprint. arXiv:1712.04621. (2017).

13. Y. Tang, Deep learning using linear support vector machines, arXiv preprint arXiv:1306.0239. (2013).

14. K. Sohn, H. Lee, and X. Yan, Learning structured output representation using deep conditional generative models, Adv. Neural Inf. Process. Syst. (2015) 34833491.

15. G. Panchal, A. Ganatra, Y. P. Kosta, and D. Panchal, Behaviour analysis of multilayer perceptrons with multiple hidden neurons and hidden layers, Int. J. Computer Theory Eng. 3(2) (2011) 332-337.

16. S. Ding, C. Su, and J. Yu, An optimizing BP neural network algorithm based on genetic algorithm, Artif. Intell. Rev. 36(2) (2011) 153-162.

17. F. H. F. Leung, H. K. Lam, S. H. Ling, and P. K. S. Tam, Tuning of the structure and parameters of a neural network using an improved genetic algorithm, IEEE Trans. Neural Netw. 14(1) (2003) 79-88. 
18. S. Jang and B. Yoon, Artificial Intelligence: A Comparative Study on Real - number Processing Method in Genetic Algorithms, Korea Inf. Process. Soc. 5(2) (1998) 361-371.

19. L. N. Smith, A disciplined approach to neural network hyper-parameters: Part 1- learning rate, batch size, momentum, and weight decay, arXiv preprint arXiv: 1803.09820. (2018).
20. J. Wroblewski, Finding minimal reducts using genetic algorithms, In Proccedings of the Second Annual Join Conference on Infromation Science. 2 (1995) 186-189.

21. D. J. Montana and L. Davis, Training feedforward neural networks using genetic algorithms, In IJCAI. 89, (1989) 762-767. 


\title{
GMAW에서 유전알고리즘을 이용한 신경망 구조 최적화를 통해 실시간 기공 형상검출에 관한 연구
}

\section{Study on Real-Time Porosity Defect Detection Through Neural Network Structure Optimization using Genetic Algorithm in GMAW}

\author{
이 동 욱*·김 성 남** 이 세 헌** \\ *한양대학교 기계공학부 \\ **한양대학교 대학원 융합기계공학과
}

\section{1. 서 론}

가스메탈아크용접(GMAW)은 불활성기체로 구성된 보 호가스로 보호되며 wire와 모재 사이에 아크를 발생시 켜 용접하는 방법이다. 또한 wire가 자동으로 공급되 어 용접로봇이나 자동화 용접이 가능하여 아연도금강판 과 함께 자동차 샤시공정에도 주로 사용된다. 하지만 아연도금강판에 GMAW가 적용될 경우 표면에 도금된 아연은 모재의 용융점보다 낮은 온도에서 기화되기 때 문에 용접부 내에 갇힌 채 아연증기가 빠져나오지 못하 여 blow hole이나 pit와 같은 기공결함이 발생된다 ${ }^{1-3)}$. 이러한 결함들은 용접품질이나 생산성을 저하하는 주된 원인이 되고 있으며) 이러한 결함을 검출하기 위 해 용접 공정이 끝나야 수행이 가능한 방사선검사나 초 음파검사와 같은 비파괴검사 대신, 아크 용접 중에 발 생된 아크전압신호의 특성을 분석하여 기공결함을 검출 하는 연구가 진행되어왔다 ${ }^{5-11)}$. 이 방법은 기존의 비파 괴 검사방법보다 비용적으로 우수하며 시간적 측면에서 도 생산성을 향상시킬 수 있다.

Deep learning 기법은 품질예측 알고리즘뿐만 아니 라 다양한 분야에 적용되고 있다 ${ }^{12-14)}$. 하지만 이러한 신경망을 이용한 연구 중 대부분은 신경망 모델의 hyper parameter를 어떻게 선정했는지에 대한 설명이 없으며, 그 값이 바로 제시되어 있는 경우가 많다. 이 는 연구자 본인이 직접 테스트를 해서 가장 잘 나온 구 조를 찾는 과정을 거치기 때문이며 이런 부분에 대해서 는 분명 개선할 필요가 있다.

Deep learning 구조에서 은닉층의 개수가 많아지면 복잡한 문제를 풀 수 있게 되지만 학습데이터셋이 적을 때나 학습 데이터가 간단한 형태로 되어있는 등 비교적 간단한 문제들을 많은 은닉층을 가진 신경망에 학습시
킬 경우 중요성이 낮은 특징 값을 추출하기 때문에 과 적합이 일어나며 모델의 일반화 성능이 낮아지게 된다 14). 이처럼 신경망의 구조에 따라 풀어낼 수 있는 문제 들이 달라지기 때문에 hyper parameter를 적절하게 선정하는 일은 매우 중요하다. 인공신경망의 hyper parameter들은 다양해서 이를 모든 경우의 수에서 테 스트를 해보고 최적의 구조를 찾는 것은 비생산적이다. 따라서 유전알고리즘을 통해 이러한 변수들을 최적화를 하는 연구들이 많이 진행되어 왔다 ${ }^{16,17)}$. 다만 유전알 고리즘은 랜덤성에 기반하여 최적 값을 찾아내는 알고 리즘으로써 표본이 많을수록 전역 최적해를 찾아내기 쉽지만 ${ }^{16)}$ 그만큼 표본이 많으면 계산 량이 많아지고 계산 시간이 오래 걸리게 되는 단점이 존재한다.

따라서 본 연구에서는 세대별 염색체의 총량(population)을 조절하여 계산시간을 단축한 새로운 유전알 고리즘을 제안한다. 유전알고리즘을 적용하기위해 아연 도금강판 GMAW실험을 수행하여 용접공정중에 발생 한 아크전압신호에서 기공발생여부에 따른 특징변수를 추출 후 심층신경망 $(\mathrm{DNN})$ 모델에 학습시켰고 $\mathrm{DNN}$ 모델의 hyper parameter를 본 연구에서 제안하는 유 전알고리즘으로 최적화하였다. 마지막으로 선행연구 ${ }^{11}$ 의 $\mathrm{DNN}$ 구조와 성능비교를 통해 제안하는 최적화 알고 리즘의 유효성을 검증하였다.

\section{2. 실 험}

\section{1 재 료}

본 연구에서는 극한강도 $590 \mathrm{Mpa}$, 두께 $2.3 \mathrm{~mm}$ 의 아연도금 열연강판을 시험 재료로 사용하였다. 사용 된 열연강판은 $800{ }^{\circ} \mathrm{C}$ 이상의 고온에서 롤 사이 슬래 브를 통과시켜 적당한 길이와 폭으로 가공한 강판이다. 재료의 아연도금두께는 약 $10 \mu \mathrm{m}$ 이고 기계적, 화학적 
Table 1 Mechanical and chemical properties of the material

\begin{tabular}{|c|c|c|c|c|c|c|c|c|c|}
\hline $\begin{array}{c}\text { Base } \\
\text { metal }\end{array}$ & \multicolumn{5}{|c|}{$\begin{array}{c}\text { Chemical } \\
\text { composition }\end{array}$} & \multicolumn{3}{c|}{$\begin{array}{c}\text { Mechanical } \\
\text { properties }\end{array}$} \\
\hline \multirow{2}{*}{$\begin{array}{c}\text { GA } \\
590\end{array}$} & $\mathrm{C}$ & $\mathrm{Si}$ & $\mathrm{Mn}$ & $\mathrm{P}$ & $\mathrm{S}$ & $\mathrm{Fe}$ & $\begin{array}{c}\text { YS } \\
(\mathrm{MPa})\end{array}$ & $\begin{array}{c}\mathrm{TS} \\
(\mathrm{MPa})\end{array}$ & $\begin{array}{c}\mathrm{EL} \\
(\%)\end{array}$ \\
\cline { 2 - 10 } & 0.0817 & 0.136 & 1.440 & 0.013 & 0.002 & $\mathrm{Bal}$. & 583 & 629 & 25 \\
\hline
\end{tabular}

특성은 Table 1에 나타내었다. 강판은 폭 $150 \mathrm{~mm}$, 길이 $180 \mathrm{~mm}$ 로 가공하였다.

\section{2 용접 장비와 절차}

정전압 직류 인버터형 용접기를 사용하여 단락이행모 드로 용접실험을 수행하였다. 전체적인 용접 시스템 구 성은 Fig. 2에 나타내었다. 용접시편은 지그 위에 lap joint방식으로 고정하였고 용접기와 지그사이의 용접전 류는 홀 센서로 측정하여 $\mathrm{DAQ}$ 장치로 전송하였고, 용 접전압은 시험편과 wire송급기로부터 $\mathrm{DAQ}$ 장비로 실 시간 계측되었다. 용접방식은 Fig. 1 과 같이 자동차 차 체 샤시 용접 현장에서 자주 적용되는 토치 각도 $45^{\circ}$, 랩조인트방식을 사용하였다.

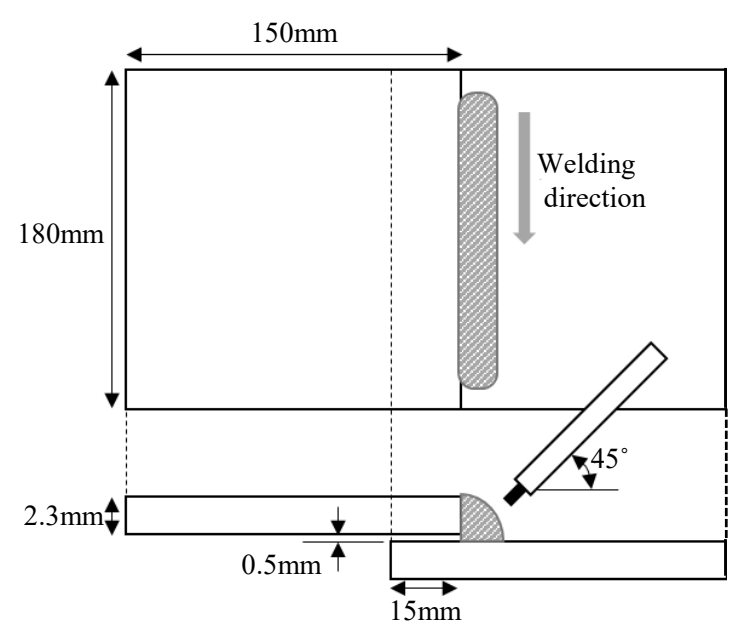

Fig. 1 Welding method and shape of steel plate

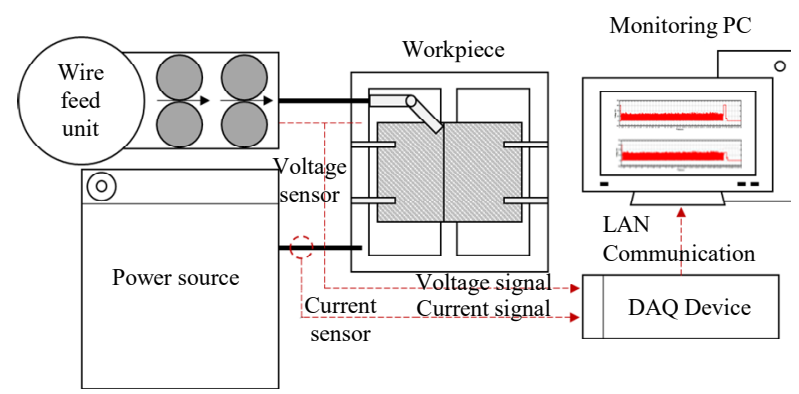

Fig. 2 Schematic diagram of welding and experimental equipment
Table 2에서와 같이 용접속도는 $600 \mathrm{~mm} / \mathrm{min}$, 컨 텍트팁과 모재간 거리(CTWD)는 $15 \mathrm{~mm}$ 로 고정하였고, 보호가스는 $90 \% \mathrm{Ar}$ 과 $10 \% \mathrm{CO}_{2}$ 비율인 혼합가스를 사용하였으며 시험편 사이의 gap은 $0.0 \mathrm{~mm}$ 와 $0.5 \mathrm{~mm}$ 로 고정하였다. 그리고 직경이 $1.2 \mathrm{~mm}$ 인 ER70S-3급 용 접 와이어를 사용했으며 와이어 송급속도는 $4 \mathrm{~m} / \mathrm{min}$ 으로 실험을 수행하였다. 신뢰도를 위해 각 조건에서 두 번의 반복실험을 진행하였다.

\section{3. 유전알고리즘}

\section{1 유전알고리즘 최적화 기법}

유전알고리즘은 각 변수들을 모든 경우에 대해서 테 스트를 해보는 것이 아닌, 부모선택, 교배연산, 돌연변 이연산 등과 같이 랜덤성에 의해서 최적해를 찾아낸다. 어떻게 풀어야 하는지 구체적인 방법이 제시되지 않은 문제라도 알고리즘 설계자가 해의 형태를 유전자구성으 로 나타낼 수 있고, 적절한 적합도 함수를 설정할 수 있다면 알고리즘으로 적절한 해가 도출되는 것이 유전 알고리즘의 큰 장점이다.

Fig. 3에 유전알고리즘의 순서도를 나타내었다. 첫 번째 세대 염색체집합을 식(1)에 나타내었다.

$$
P_{1}=\left\{p_{1,1}, p_{1,2}, p_{1,3}, \cdots, p_{1, n}\right\}
$$

위 식에서 $P_{i}$ 는 $\mathrm{i}$ 번째 세대의 염색체 집합, $n$ 은 염 색체의 총량(population), $p_{i, j}$ 는 $\mathrm{i}$ 세대의 $\mathrm{j}$ 번째 염색 체이다. 1 세대의 첫번째 염색체 $\left(p_{1,1}\right)$ 가 가지는 유전정 보는 식(2)와 같다.

$$
p_{1,1}=\left\{q_{1,1,1}, q_{1,1,2}, q_{1,1,3}, \cdots, q_{1,1, m}\right\}
$$

$q$ 는 각 염색체가 가지는 유전정보의 값들, $\mathrm{m}$ 은 각 염색체가 가지는 유전정보의 종류개수, $q_{i, j, k}$ 는 $\mathrm{i}$ 세대 $\mathrm{j}$ 번째 염색체 $p_{i, j}$ 의 $\mathrm{k}$ 번째 유전정보값이다. 대체로 유전

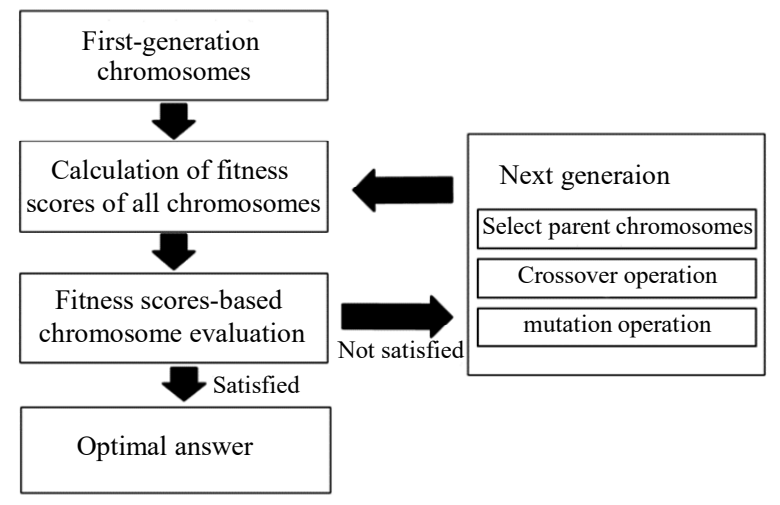

Fig. 3 Genetic algorithm flowchart 
정보 $q$ 값은 초기세대에서 최소, 최대값 제한을 두고 랜 덤하게 값을 부여한다.

유전정보 값이 부여된 염색체들이 있는 1 세대 염색 체 집합 $P_{1}$ 의 염색체 $\mathrm{n}$ 개 모두를 적절한 적합도 함수 로 평가를 한다.

$$
p_{i, j, s c o r e}=f\left(p_{1, j}\right)
$$

$f$ 는 적합도 함수이며 유전알고리즘 설계자 본인이 직접 구성해야 한다. 적절한 함수 $f$ 로 평가된 염색체들 중 하나 이상이 기대한 적절치 이상의 점수를 가지게 되면 최적해가 되며 그렇지 않으면 점수가 부여된 1세 대 염색체들로 다음세대를 생성한다. 적합도 점수가 높 을수록 높은 확률로, 두 개의 염색체를 확률적으로 선 정하는 방법인 룰렛 휠 선택을 적용하였다. 아래 식(4), (5)와 같이 1 세대의 $\mathrm{a}$ 번째 $\left(p_{1, a}\right), \mathrm{b}$ 번째 $\left(p_{1, b}\right)$ 염색체가 선정이 되었다면 교차연산을 수행한다.

$$
\begin{aligned}
& p_{1, a}=\left\{q_{1, a, 1}, q_{1, a, 2}, q_{1, a, 3}, \cdots, q_{1, a, m}\right\} \\
& p_{1, b}=\left\{q_{1, b, 1}, q_{1, b, 2}, q_{1, b, 3}, \cdots, q_{1, b, m}\right\}
\end{aligned}
$$

실수형태의 유전자 값을 갖는 염색체의 교차방법으로 는 이미 여러가지 제안된 방법 ${ }^{18)}$ 중 산술교차를 채택하 였다. 교차 후 생성된 2 세대 첫번째 자손 염색체를 $p_{2,1}$ 라고 하면 식(6)과 같다.

$$
p_{2,1}=\left\{\left\{q_{2,1,1}, q_{2,1,2}, q_{2,1,3}, \cdots, q_{2,1, m}\right\}\right\}
$$

산술교차에 의해 $p_{2,1}$ 의 $\mathrm{k}$ 번째 유전자 값 $q_{2,1, k}$ 는 식 (7)과 같다.

$$
q_{2,1, k}=\alpha_{k} \cdot q_{1, a, k}+\left(1-\alpha_{k}\right) \cdot q_{1, b, k}
$$

$\alpha_{k}$ 는 0 에서 1 사이의 임의의 값을 갖는다. 즉, 자손 $p_{2,1}$ 의 $\mathrm{k}$ 번째 유전자 값 $q_{2,1, k}$ 는 1 세대 $\mathrm{a}$ 번째 염색체의 $\mathrm{k}$ 번째 유전자값과 1 세대 $\mathrm{b}$ 번째 염색체의 $\mathrm{k}$ 번째 유전자 값의 랜덤한 사이값이 된다. 이렇게 교차연산을 수행한 후 특정 확률에 의해 유전자 값을 임의로 변경시키는 돌연변이 연산을 수행하면 2세대 염색체들이 된다. 그 리고 적합도 함수 $f$ 로 평가를 다시하여 다음세대를 반 복할 지 결정한다.

본 연구에서는 이와 같은 유전알고리즘을 Fig. 4과 같이 적용하여 GMAW 결함예측 인공신경망의 hyper parameter를 최적화하였다. GMAW실험 후에 아크전 압파형의 특징변수 추출, 용접위치에 따른 기공률을 학 습데이터로 설정하였다. 유전알고리즘을 적용하여 신경 망의 최적hyper parameter 도출 후 최적화된 신경망

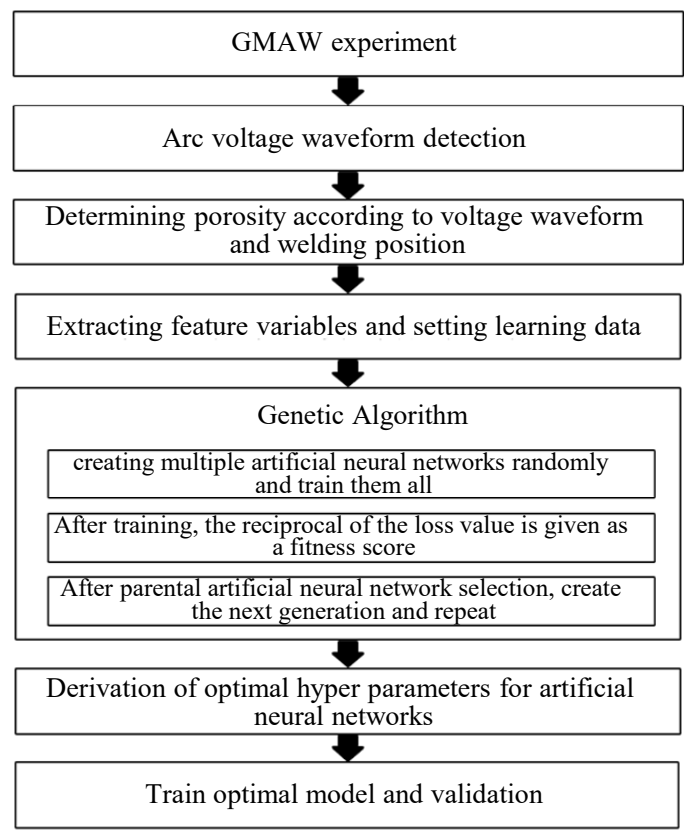

Fig. 4 Genetic algorithm optimization flow chart

을 학습시키고 검증하였다.

최적화할 신경망의 은닉층 활성화 함수로는 ReLU함 수를 사용하였다. 그리고 output의 경우 결함이 있으 면 1 , 결함이 없으면 0 을 출력하도록 해서 다중 클래 스 분류 처리에 효과적인 softmax함수를 출력층의 활 성화함수로 사용하였다.

\section{2 딥러닝 hyper parameter 선정}

Fig. 5와 같은 심층신경망은 퍼셉트론을 여러 층으로 배치한 구조이다. 오차 역전파 알고리즘을 이용한 가중 치 수정을 통해 각 노드의 최적 가중치 값을 찾는 방식 으로 학습이 이루어진다.

본 연구에서 최적화할 hyper parameter는 우선 은 닉층의 개수와 각 은닉층이 가지게 되는 노드의 개수이 다. 이 개수들이 너무 많아지면 과적합(overfitting)현 상이 일어나 신경망의 범용성이 떨어진다 ${ }^{15)}$. 그리고 인 공신경망 학습과정에 있어서도 여러가지 parameter들

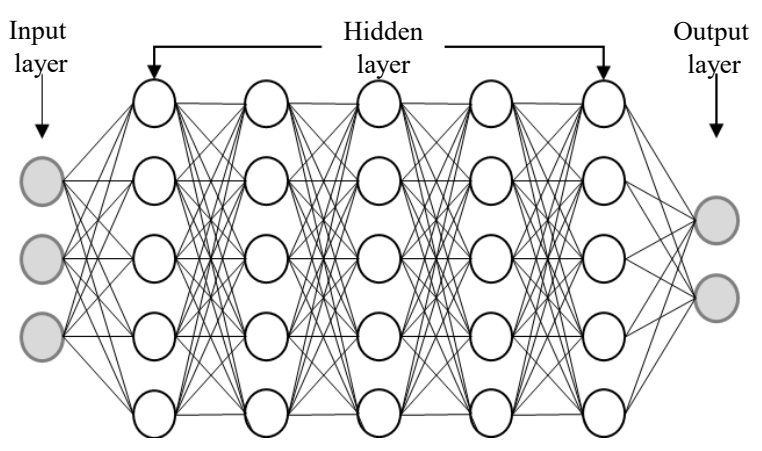

Fig 5 Deep neural network structure 
Table 3 Hyper parameters from previous research ${ }^{11)}$

\begin{tabular}{|c|c|}
\hline \multicolumn{2}{|c|}{ Hyper parameters from previous research $^{11)}$} \\
\hline Number of hidden layer & 4 \\
\hline Number of node in each layer & $24,24,24,24$ \\
\hline Learning rate & 0.01 \\
\hline Batch size & 32 \\
\hline Dropout rate & 0.5 \\
\hline
\end{tabular}

이 있는데 그 중에 learning rate와 batch size, dropout rate ${ }^{19)}$ 도 함께 최적화를 진행하였다. 최적화 후에, 선행연구 ${ }^{11)}$ 의 $\mathrm{DNN}$ 구조와의 결과를 비교하기 위해 Table 3에 정리하였다.

\section{3 유전알고리즘 기반 최적화}

3.2절에서 선정한 hyper parameter들을 염색체에 실수형태 유전자 값으로 부여하였고 염색체가 가지는 유 전정보는 각각 은닉층의 수와 각 층의 노드 수, learning rate, batch size, dropout rate이다. 각 유전자 값 의 범위는, 은닉층의 수는 $1 \sim 10$ 층, 노드 개수는 각 은닉층마다 10 50 개, learning rate는 0 0.2, batch size는 100 10000, dropout rate는 0 0.8 의 범위로 설정하였다.

1 세대의 염색체는 위 범위 내의 유전자 값으로 랜덤 하게 구성하였다. 본 연구에서는 1 세대 population을 256 으로 선정하였다. 임의로 생성된 256 개의 염색체 들 각각에 대응되는 인공신경망들이 학습데이터에 적합 한 구조인지 알아보기 위해 모두 학습을 시킨다. 학습 완료후에, 학습데이터와는 다른 데이터로 구성된 검증 데이터(test data)에 대해 발생하는 loss(MSE)의 역 수값을 적합도 점수로써 부여하였다. 점수가 높을수록 좋은 염색체라고 설명할 수 있다.

이렇게 1 세대의 모든 염색체에 적합도 점수가 계산 되면 이 점수를 가중치로 염색체에 확률을 부여하는 룰 렛 휠 선택방식으로, 부모염색체를 선정하였다. 그 후 산술교차, 돌연변이 연산을 통해 2 세대의 염색체를 만 들었다. 기존의 유전알고리즘이라면 앞선 과정을 계속 해서 반복하면 되지만 본 연구에서는 세대별 염색체 개 수(population)에 몇 가지 규칙을 더 적용하였다.

유전알고리즘을 사용한 기존의 타 논문 ${ }^{20,21)}$ 들은 보 통 모든 세대가 동일한 population을 갖는다. Fig. 6 (a)는 기존의 유전알고리즘을 본 최적화연구에 적용시 켰을 때의 예시이다. Fig. 6 (b)는 본 논문에서 새롭 게 제시하는 개선된 알고리즘이다. 세대를 거칠수록 염

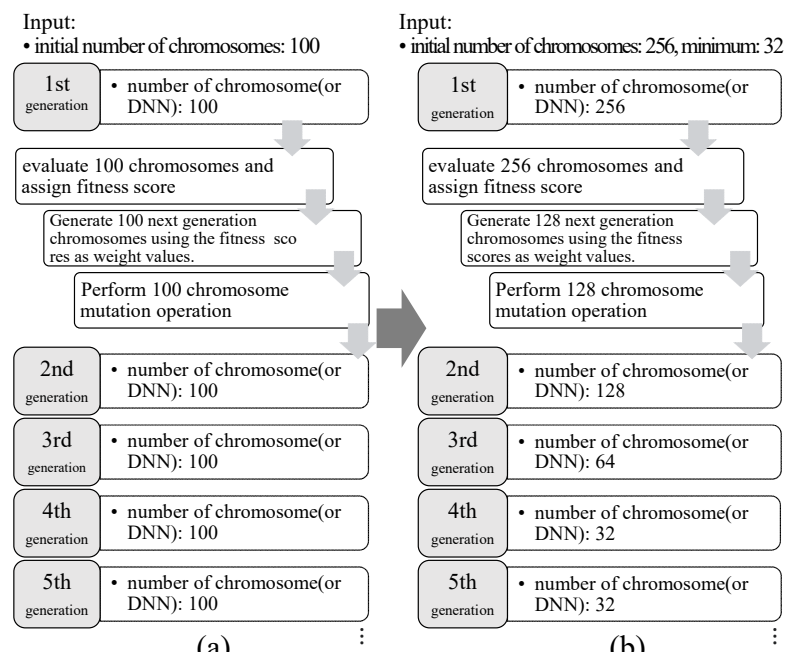

(a)

(b)

Fig. 6 Improved genetic algorithm, (a) Usual genetic algorithm, (b) Improved genetic algorithm in this study

색체의 총량을 줄이며 진행함과 동시에 이전 세대보다 epoch를 조금 증가시켜 계산하였다. 즉 이전 세대에서 선별된 자손 염색체들을 집중 분석하였다. 1 세대와 2 세대 사이의 과정은 Fig. 6에 적어 놓았으며 2세대 이 후로는 동일한 방법을 적용하였다. 그리고 최소 염색체 개수도 설정하여 한 세대가 가지는 염색체 개수가 너무 작아지는 것을 방지한다. 이렇게 개선을 하여 진행한 결과, 비슷한 최적 hyper parameter를 출력해내는데 걸린 시간은 개선하기 전보다 $30 \%$ 정도 단축되었으며 단축된 시간을 이용해, 1 세대 염색체 수(population) 를 기존의 알고리즘보다 2 배정도 더 많이 설정하여 초 기 염색체들의 다양성도 개선하였다.

\section{4. 결과 및 고찰}

\section{1 신호분석 및 특징 추출}

용접실험에서 $10 \mathrm{kHz}$ 의 sampling rate로 20 초 동 안 계측된 용접전압파형, bead shape, x-ray image 를 Fig. 7에 각각 나열하였다. 파형전압의 데이터는 계 측된 raw데이터의 0.1 초 구간(1000 개 데이터)의 샘플링 데이터를 하나의 window로 지정하였으며 90 $\%$ 씩 오버랩시켜 각각의 window에서 특징변수들을 도 출하였다. 0.1 초구간 window에서 생성된 단락이행모 드의 아크전압파형을 Fig. 8에 나타내었으며 각 변수들 은 0.1 초 구간의 1000 개 데이터 사이에서 도출되었 다. $V_{p}$ 와 $V_{s}$ 는 각각 0.1 초 동안의 최대, 최소 전압데 이터 값이며, $s[V]$ 는 0.1 초 데이터의 표준편차, $s\left[V_{s}\right]$ 는 5 개의 순간단락된 전압데이터(주황색 원)의 표준 

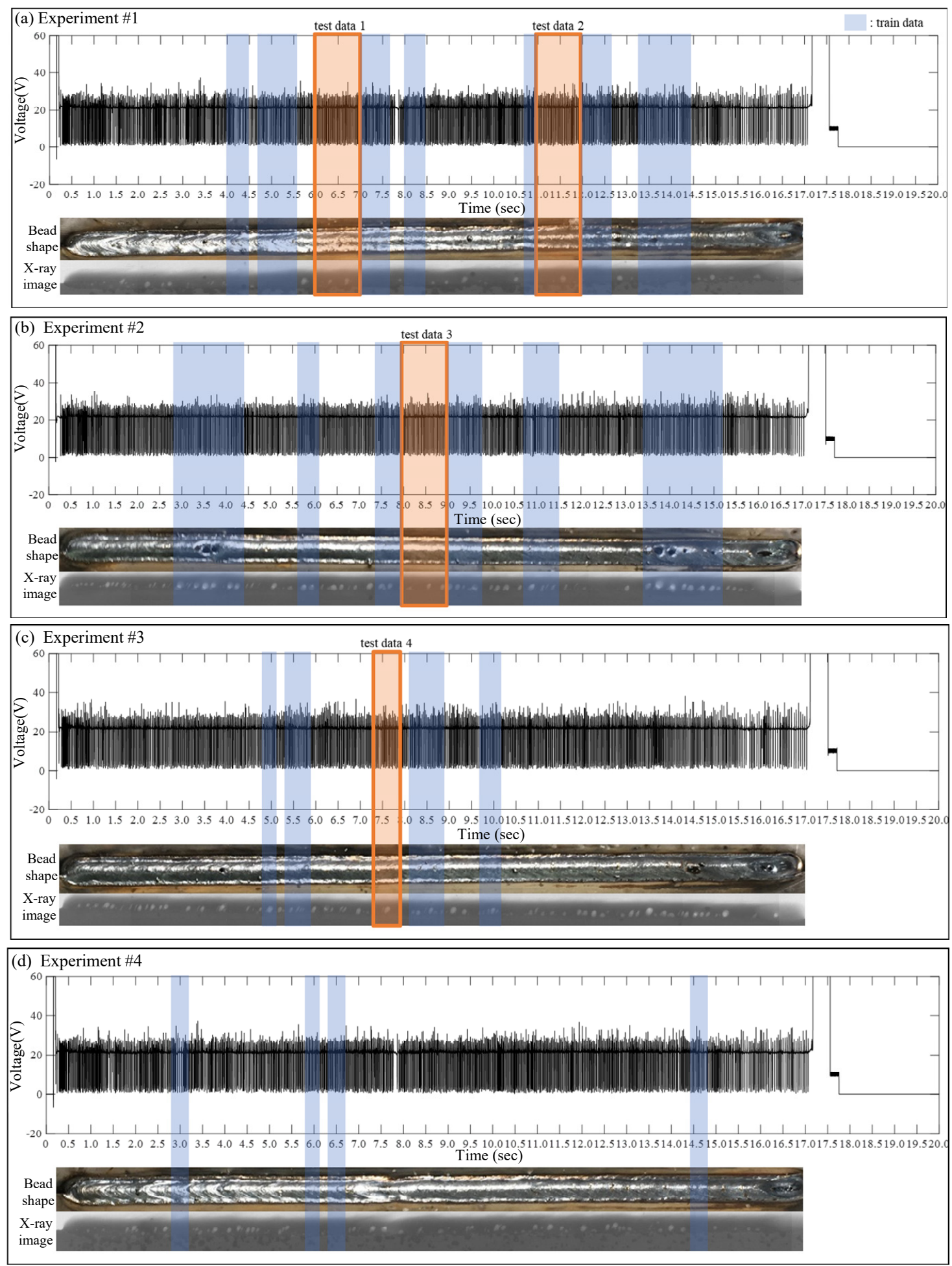

Fig. 7 Voltage waveform, bead shape, $x$-ray image and train, test data, (a) result of experiment \#1, (b) result of experiment $\# 2$, (c) result of experiment $\# 3$, (d) result of experiment $\# 4$

편차이고 $s\left[V_{p}\right]$ 는 5 개의 피크 전압데이터(파란색 원) 의 표준편차이다. $s\left[T_{a}\right]$ 는 0.1 초내 아크기간들의 표 준편차, $s\left[V\left(T_{s}\right)\right]$ 와 $s\left[V\left(T_{a}\right)\right]$ 는 각각 단락기간과 아크기간동안 계측된 전압들의 표준편차값이다. Table 4에 각 변수를 정리하였다.
4.2 유전알고리즘을 이용한 최적화 결과

3.2절에서 제시한 알고리즘에 기반하여 아래 Table 5 의 변수들로 최적화를 진행하였다. 최적화 과정 중에 출현한 염색체들을 모두 Table 6에 나타내었다. 적합 


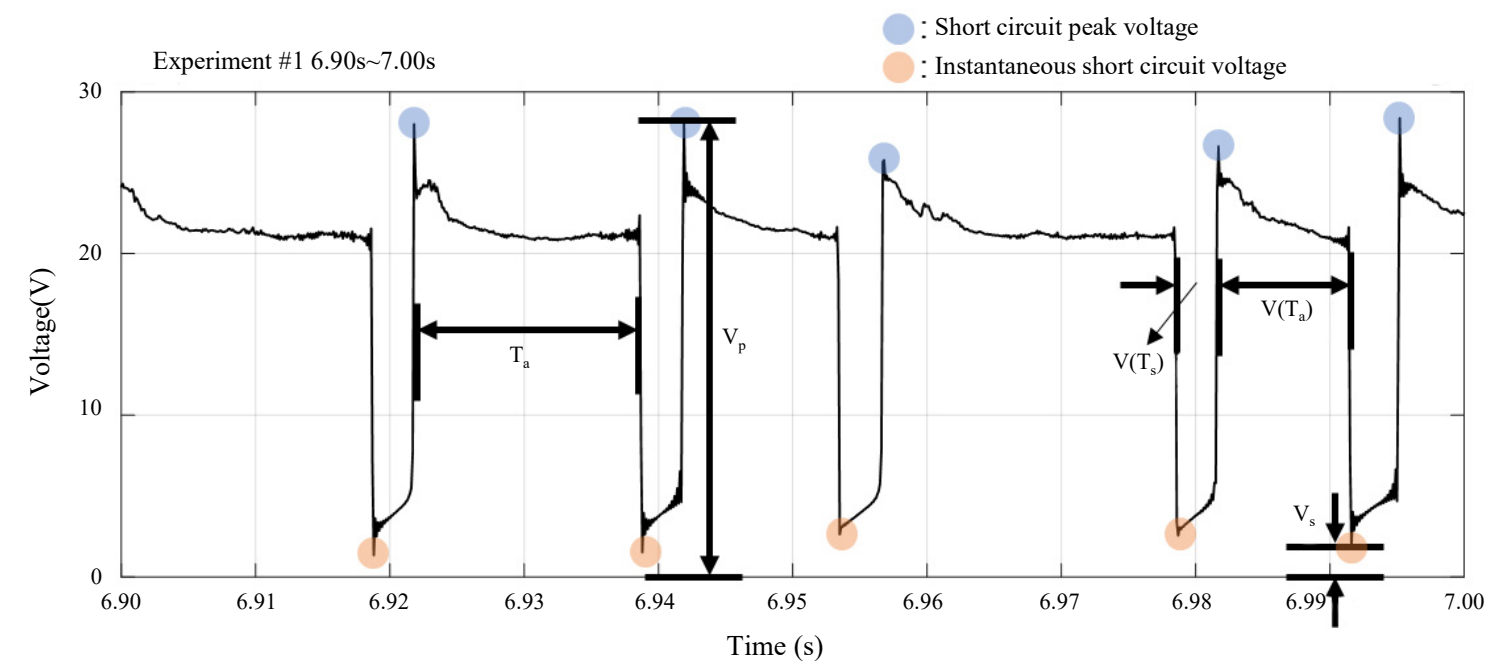

Fig. 8 Arc voltage waveform and feature variables

Table 4 Feature variables

\begin{tabular}{|c|l|}
\hline Variables & \multicolumn{1}{|c|}{ Name } \\
\hline$s[V]$ & Standard deviation of voltage \\
\hline$V_{p}$ & peak voltage \\
\hline$V_{s}$ & short circuit voltage \\
\hline$s\left[V_{s}\right]$ & $\begin{array}{l}\text { Standard deviation of } \\
\text { instantaneous short circuit voltage }\end{array}$ \\
\hline$s\left[V_{p}\right]$ & $\begin{array}{l}\text { Standard deviation of } \\
\text { short circuit peak voltage }\end{array}$ \\
\hline$s\left[T_{a}\right]$ & Standard deviation of arc time \\
\hline$s\left[V\left(T_{s}\right)\right]$ & $\begin{array}{l}\text { standard deviation of } \\
\text { voltage during short circuit time }\end{array}$ \\
\hline$s\left[V\left(T_{a}\right)\right]$ & $\begin{array}{l}\text { standard deviation of } \\
\text { voltage during arc time }\end{array}$ \\
\hline
\end{tabular}

Table 5 Genetic algorithm variables

\begin{tabular}{|l|c|}
\hline \multicolumn{1}{|c|}{ Variables } & Value \\
\hline Initial number of chromosomes & 256 \\
\hline Minimum number of chromosomes & 64 \\
\hline Maximum generation & 15 \\
\hline mutation probability & $15 \%$ \\
\hline
\end{tabular}

도 점수 값을 기준으로 가장 높았던 신경망부터 내림차 순으로 정렬하였고, 출현한 염색체의 수는 모두 1216 개(1세대 256 개 +2 세대 128 개 +3 세대 15 세대 64 개)였으며 상위 12 개를 Table 6에 나타내었다.

Table 6 Neural network optimization results for GMAW experiment data

\begin{tabular}{|c|c|c|c|c|c|c|c|c|c|c|c|c|c|c|c|}
\hline \multirow{2}{*}{\begin{tabular}{|c|} 
Hidden \\
layer \\
number
\end{tabular}} & \multicolumn{10}{|c|}{ Number of nodes in each hidden layer } & \multirow{2}{*}{$\begin{array}{l}\text { batch } \\
\text { size }\end{array}$} & \multirow{2}{*}{$\begin{array}{l}\text { learning } \\
\text { rate }\end{array}$} & \multirow{2}{*}{$\begin{array}{l}\text { dropout } \\
\text { rate }\end{array}$} & \multirow{2}{*}{$\begin{array}{c}\text { Fitness } \\
\text { scores }\end{array}$} & \multirow{2}{*}{$\begin{array}{l}\text { Generation } \\
\text { that } \\
\text { emerged }\end{array}$} \\
\hline & $1 \mathrm{st}$ & 2 nd & 3 rd & 4 th & 5 th & 6 th & 7 th & 8 th & 9 th & 10 th & & & & & \\
\hline 3 & 37 & 31 & 40 & 32 & 16 & 24 & 20 & 14 & 19 & 18 & 5671 & 0.009521 & 0.105286 & 7.538489 & 14 \\
\hline 3 & 21 & 21 & 33 & 48 & 11 & 29 & 22 & 45 & 34 & 42 & 4500 & 0.025116 & 0.086827 & 7.513469 & 15 \\
\hline 3 & 34 & 36 & 31 & 32 & 36 & 45 & 27 & 36 & 34 & 24 & 4652 & 0.017252 & 0.072461 & 7.439683 & 6 \\
\hline 3 & 39 & 20 & 49 & 34 & 35 & 31 & 44 & 32 & 24 & 24 & 6098 & 0.02577 & 0.077352 & 7.435625 & 13 \\
\hline 2 & 49 & 30 & 25 & 39 & 30 & 25 & 43 & 28 & 32 & 25 & 4836 & 0.019425 & 0.163282 & 7.429222 & 4 \\
\hline 3 & 39 & 25 & 34 & 47 & 33 & 31 & 34 & 31 & 33 & 35 & 6394 & 0.03833 & 0.135442 & 7.423678 & 5 \\
\hline 5 & 30 & 22 & 33 & 46 & 29 & 33 & 23 & 47 & 36 & 29 & 3028 & 0.02122 & 0.099924 & 7.419714 & 13 \\
\hline 2 & 35 & 37 & 31 & 37 & 34 & 45 & 24 & 30 & 23 & 20 & 4515 & 0.051841 & 0.069824 & 7.404039 & 7 \\
\hline 1 & 32 & 39 & 41 & 36 & 30 & 26 & 38 & 24 & 35 & 34 & 5311 & 0.036818 & 0.1495 & 7.380273 & 14 \\
\hline 2 & 29 & 37 & 29 & 23 & 23 & 25 & 30 & 32 & 33 & 35 & 6800 & 0.038247 & 0.149579 & 7.376929 & 4 \\
\hline 3 & 37 & 27 & 13 & 31 & 42 & 31 & 31 & 27 & 33 & 34 & 2158 & 0.033415 & 0.085455 & 7.372247 & 11 \\
\hline 3 & 41 & 28 & 28 & 27 & 25 & 31 & 32 & 29 & 30 & 40 & 2614 & 0.031224 & 0.082894 & 7.366977 & 10 \\
\hline
\end{tabular}


은닉층의 최댓값을 10 층으로 설정하였지만 상위 염 색체들의 은닉층은 3 층으로 수렴한 것을 확인할 수 있 었다. 이 결과로부터 인공신경망의 은닉층 수가 높을수 록 항상 좋은 것은 아님을 알 수 있었다. 또한 overfitting과 관련하여 기존의 연구15) 들과 일치한 결과가 나타났다. batch size는 5000, learning rate는 약 0.02 , 그리고 dropout rate는 0.1 내외의 경향을 보였 다. learning rate의 최대값을 0.2 , dropout rate의 최대값을 0.8 로 두고 최적화를 진행했으므로 의미 있 는 최적 값으로 판단된다. Table 6에서 적합도 점수가 가장 높았던 염색체 (b)와 Table 3에서 제시된 선행연 구 DNN의 인공신경망 구조(a)를 아래 Table 7에 비 교하였다. Table 7의 선행연구 $\mathrm{DNN}$ 모델(a)과 최적 화된 모델(b)에 GMAW용접데이터를 1500 epochs씩 학습 후 test data에 대한 결함 예측결과와 bead형 상, x-ray사진을 Fig. 9에, 그에 대한 자세한 수치는 Table 8에 각각 나타내었다.

검증을 위해 사용된 test data의 총 개수는 361 개 다. 선행연구의 DNN 모델은 323 개를 정확하게 분류

Table 7 Comparison of hyper parameters, (a) DNN structure from previous research, (b) Optimized GADNN structure

\begin{tabular}{|l|c|c|}
\hline & $\begin{array}{l}\text { DNN structure from } \\
\text { previous research (a) }\end{array}$ & $\begin{array}{c}\text { Optimized GA- } \\
\text { DNN structure (b) }\end{array}$ \\
\hline $\begin{array}{l}\text { Number of } \\
\text { hidden layer }\end{array}$ & 4 & 3 \\
\hline $\begin{array}{l}\text { Number of node } \\
\text { in each layer }\end{array}$ & $24,24,24,24$ & $37,31,40$ \\
\hline learning rate & 0.01 & 0.009521 \\
\hline batch size & 32 & 5671 \\
\hline dropout rate & 0.5 & 0.105286 \\
\hline
\end{tabular}

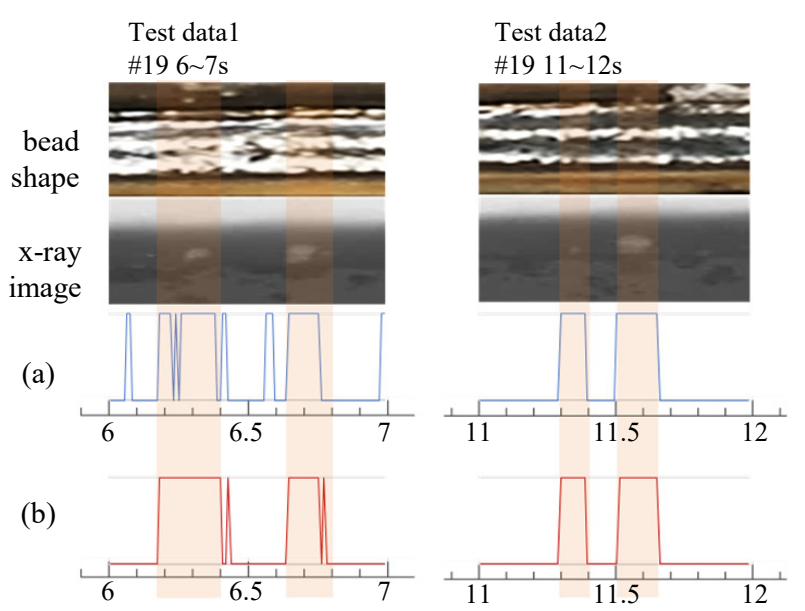

Table 8 Predictive accuracy for each model

\begin{tabular}{|l|c|c|c|c|}
\hline & $\begin{array}{c}\text { Total } \\
\text { test data }\end{array}$ & True & Error & accuracy \\
\hline $\begin{array}{l}\text { DNN structure } \\
\text { from previous } \\
\text { research }\end{array}$ & 361 & 323 & 38 & 89.4737 \\
\cline { 1 - 3 } $\begin{array}{l}\text { Optimized GA- } \\
\text { DNN structure }\end{array}$ & & 336 & 25 & 93.0748 \\
\hline
\end{tabular}

하였으며 오류개수는 38 개, 정확도는 $89.5 \%$ 였다. 유전알고리즘으로 최적화된 $\mathrm{DNN}$ 모델은 336 개를 정확 하게 분류하였으며 오류개수는 25 개, 정확도는 $93.1 \%$ 였다. 최적화한 모델의 예측 정확도가 $3.60 \%$ 더 우수 했다. 오차의 개수는 38 개에서 25 개로 그 감소율은 $34.2 \%$ 였다.

\section{3 최적화 후 실시간 적용을 위한 시스템}

본 연구에서는 Fig. 10과 같이 최적화된 GA-DNN

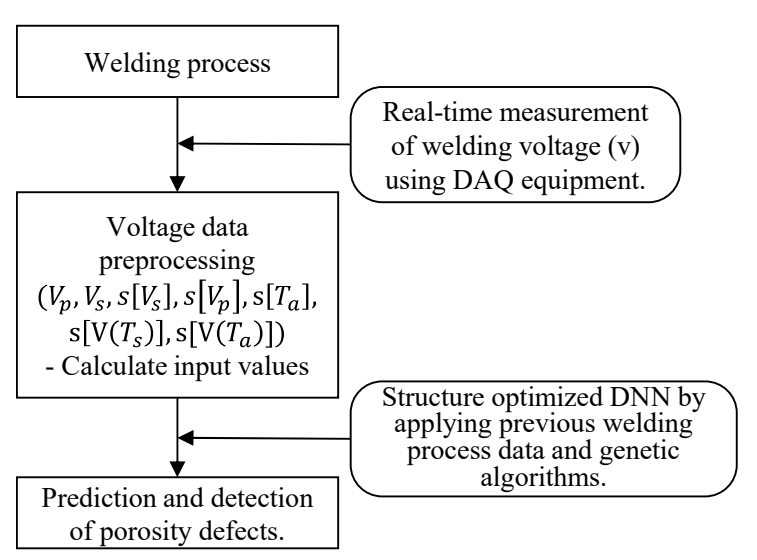

Fig. 10 Process of GMAW porosity defects prediction with GA-DNN structure in real-time
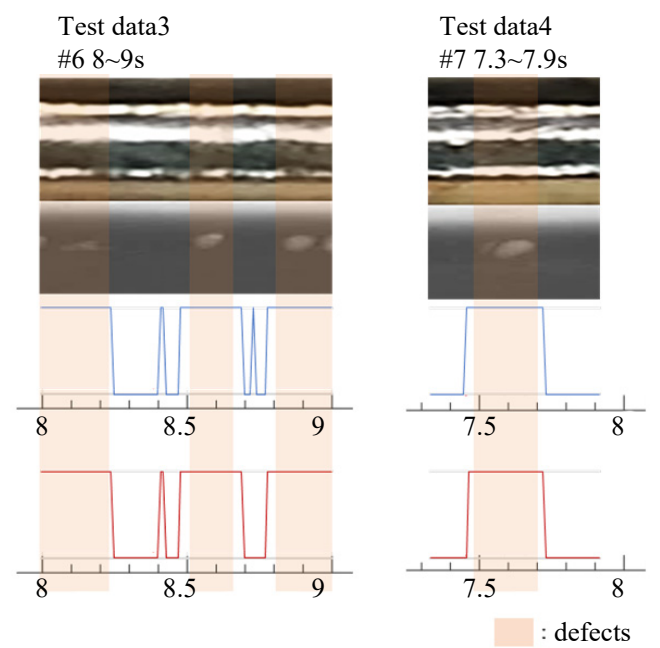

Fig. 9 Porosity defects prediction from DNN, (a) Prediction from previous research DNN structure, (b) Prediction from optimized GA-DNN structure 
구조를 활용하여 GMAW로부터 발생하는 기공결함을 실시간으로 예측하는 시스템을 제안한다. 선행연구 ${ }^{11}$ 와 마찬가지로, 용접전압을 $\mathrm{DAQ}$ 장비로 실시간 계측하여 데이터 전처리 과정을 통해 특징변수를 추출하여 입력 값으로 활용한다. 유전알고리즘으로 최적화를 하는 데 에는 적지 않은 시간이 소요되지만, 이전 용접공정의 데이터와 유전알고리즘으로 미리 최적화가 된 $\mathrm{DNN}$ 구 조에 입력 값을 넣으면 기공결함의 위치 예측 값은 바 로 계산된다. $\mathrm{DNN}$ 구조는 현장에서 용접공정을 반복 수행함에 따라 얻어진 용접데이터를 활용하여 주기적으 로 최적화, 개선할 수 있을 것으로 사료된다.

\section{5. 결 론}

본 연구에서는 GMAW 실험결과로부터 특징변수를 추출하였고 유전알고리즘에 기반하여 기공생성여부를 판단하는 심층신경망의 hyper parameter를 최적화한 결과 그 성능이 향상된 것을 확인할 수 있었다. 이런 방식을 활용하여 사용되는 용접장비가 달라지거나 자동 차 종류가 달라지는 등, 각기 다른 용접환경에 알맞은 신경망을 각각, 자동 설계가 가능하다. 이렇게 기공결 함 검출 알고리즘으로서 시간, 비용적 측면의 개선을 더 극대화할 수 있을 것이다. 더 나아가 이 유전알고리 즘으로 용접데이터 뿐만 아니라 다른 학습데이터에 대 해서도 적용할 가능성이 있을 것으로 사료된다.

본 연구로부터 발전한 부분 및 결론을 아래와 같이 정리하였다.

1) GMAW공정으로부터 발생되는 아크전압파형을 실시간으로 계측하여 데이터 전처리과정을 통해 특징변 수를 도출하였다.

2) 본 연구에서 제안한 새로운 유전알고리즘을 적용 해본 결과, 이전보다 $30 \%$ 정도의 계산시간이 단축되 어, 1 세대의 염색체 개수를 증가시켜서 초기 염색체의 다양성을 개선하였다.

3) 최적화 결과를 검증해본 결과 유전알고리즘으로 최적화된 $\mathrm{DNN}$ 모델의 예측 정확도는 $93.1 \%$ 였으며 선행연구 $\mathrm{DNN}$ 모델의 예측률보다 $3.60 \%$ 증가하였다.

다만 본 알고리즘의 범용성을 높여 다양한 곳에 적용 하기 위해서는 layer의 활성화함수 적용 등 세세한 부 분도 자동으로 선정되게 하는것과 같은 개선점이 필요 하며 향후 연구에서 해당 문제점을 개선해 나갈 계획이다.

ORCID: Dongwook Lee: https://orcid.org/0000-0003-0426-2238 ORCID: Chengnan Jin: https://orcid.org/0000-0001-7964-5466 ORCID: Sehun Rhee: https://orcid.org/0000-0002-0039-5650

\section{References}

1. S. Kodama, Y. Ishida, S. Furusako, M. Saito, Y. Miyazaki, and T. Nose, Arc Welding Technology for Automotive Steel Sheets, Nippon Steel Technical Report. 103 (2013) 83-90.

2. Y. Mukai, A. Nishimura, A. Nakajima, and K. Oku, $\mathrm{CO}_{2}$ welding of galvanized steel, Weld. Int. 4(2) (1990) 123-127.

3. M. Uchihara, Joining technologies for automotive steel sheets, Weld. Int. 25(04) (2011) 249-259.

4. K. Yasuda, Avoidance of blowhole in arc welding of galvanized steel sheets, In 5th International Symposium of JWS. (1990).

5. M. J. Kang and S. Rhee, The statistical models for estimating the amount of spatter in the short circuit transfer mode of GMAW, Weld. J. 80(1) (2001) 1-8.

6. S. K. Kang, H. S. Moon, and S. J. Na, A study on determining arc stability using weight of spatter, J. Korean Weld. Join. Soc. 15(6) (1997) 527-534.

7. C. S. Wu, J. Q. Gao, and J. K. Hu, Real-time sensing and monitoring in robotic gas metal arc welding, Meas. Sci. Technol. 18(1) (2006) 303-310.

8. Z. Zhang, X. Chen, H. Chen, J. Zhong and S. Chen, Online welding quality monitoring based on feature extraction of arc voltage signal, Int. J. Adv. Manuf. Technol. 70 (9-12) (2014) 1661-1671.

9. S. J. Na and H. S. Moon, Signal processing algorithm for analysis of welding phenomena, J. Korean Weld. Join. Soc. 14(4) (1996) 24-32.

10. J. S. Sin, J. W. Kim, and S. J. Na, A Study on Monitoring of Welding Waveforms in Gas Metal Arc Welding, $J$. Korean Weld. Join. 9(03) (1991) 34-40.

11. S. Shin, C. Jin, J. Yu, and S. Rhee, Real-time detection of weld defects for automated welding process base on deep neural network, Metals. 10(3) (2020) 389. https://doi.org/10.3390/met10030389

12. L. Perez and J. Wang, The effectiveness of data augmentation in image classification using deep learning, arXiv preprint. arXiv:1712.04621. (2017).

13. Y. Tang, Deep learning using linear support vector machines, arXiv preprint arXiv:1306.0239. (2013).

14. K. Sohn, H. Lee, and X. Yan, Learning structured output representation using deep conditional generative models, Adv. Neural Inf. Process. Syst. (2015) 34833491.

15. G. Panchal, A. Ganatra, Y. P. Kosta, and D. Panchal, Behaviour analysis of multilayer perceptrons with multiple hidden neurons and hidden layers, Int. J. Computer Theory Eng. 3(2) (2011) 332-337.

16. S. Ding, C. Su, and J. Yu, An optimizing BP neural network algorithm based on genetic algorithm, Artif. Intell. Rev. 36(2) (2011) 153-162.

17. F. H. F. Leung, H. K. Lam, S. H. Ling, and P. K. S. Tam, Tuning of the structure and parameters of a neural network using an improved genetic algorithm, IEEE Trans. Neural Netw. 14(1) (2003) 79-88. 
18. S. Jang and B. Yoon, Artificial Intelligence: A Comparative Study on Real - number Processing Method in Genetic Algorithms, Korea Inf. Process. Soc. 5(2) (1998) 361-371.

19. L. N. Smith, A disciplined approach to neural network hyper-parameters: Part 1- learning rate, batch size, momentum, and weight decay, arXiv preprint arXiv: 1803.09820. (2018).
20. J. Wroblewski, Finding minimal reducts using genetic algorithms, In Proccedings of the Second Annual Join Conference on Infromation Science. 2 (1995) 186-189.

21. D. J. Montana and L. Davis, Training feedforward neural networks using genetic algorithms, In IJCAI. 89, (1989) 762-767. 